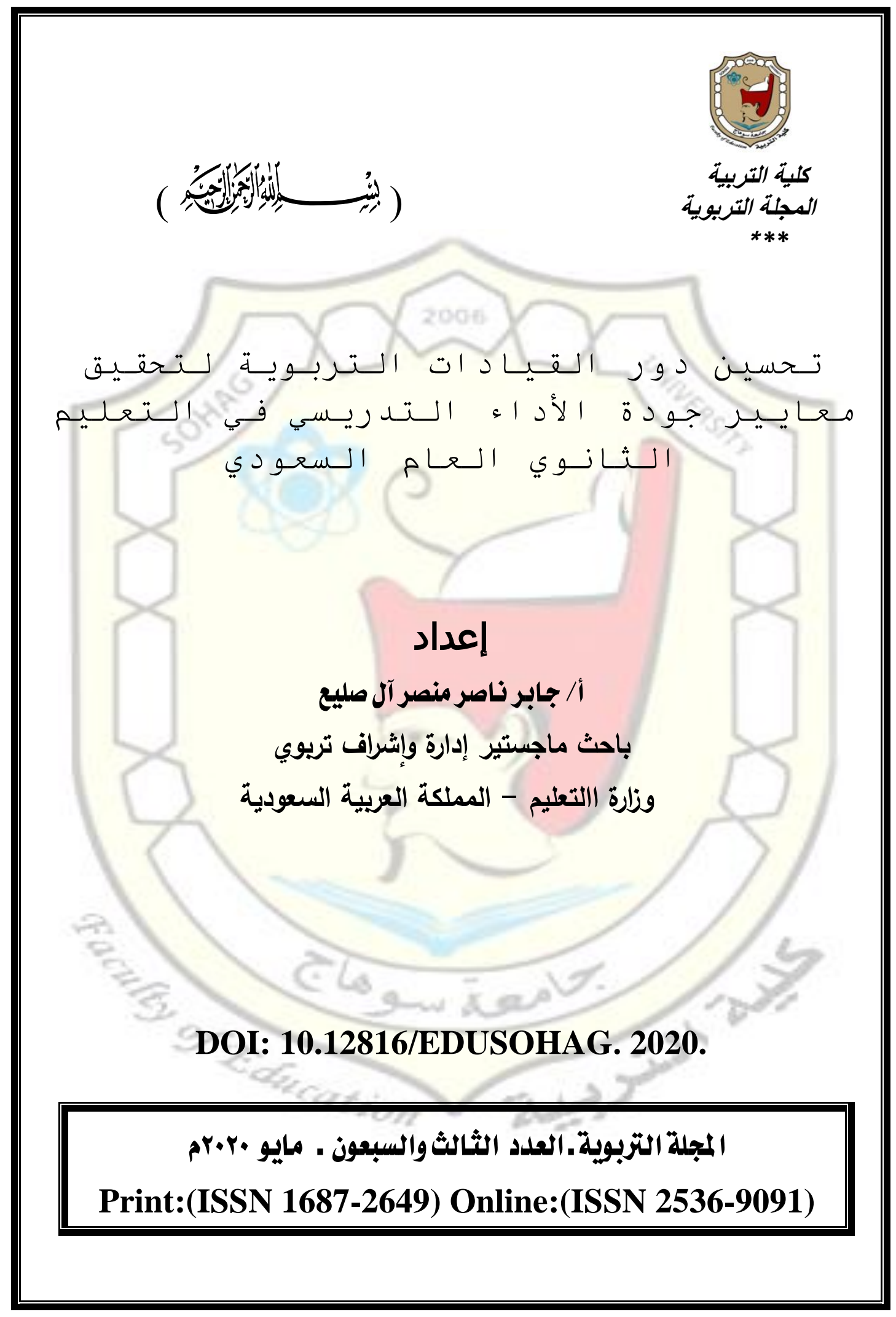




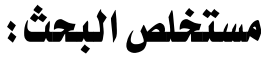

هدفت الدراسة إلى تعرف مدى تحقق معايير جودة الأداء التدريسي في المرحلة الثانوية بمدارس مدينة نجران، وتعرف معايير جودة الأداء التدريسي في واقع السياسات الرسمية للمدرسة السعودية، والكثف عن الانتقادات والصعويات التي تواجه واقع الأداء التدريسي في في ولتي المدرسة الثانوية، وقد استخدم الباحث المنهج الوصفي التحليلي، وتم اخذ عينة عشوائية من المشرفين التريويين للمواد الدراسية، وكذلك القيادات المدرسية والوكلاء في المدارس الثانوية

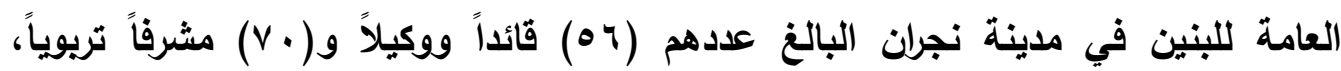
وأظهرت نتائج الدراسة دور القائد المدرسي في توفير الدورات التدريبية المناسبة للإدارة المدرسية، وعمل دورات تدريبية خاصة للمدرس حديث التخرج، ومنح الأنثطة الوطنية في المجالات الإدارية والتعليمية، كذلك أوضحت النتائج الصعويات التي تواجه القائد في كثرة الأعباء والمهام المنوطة لقائد المدرسة خارج المهام المدرسية، وقد انتهت الدراسة إلى عدد من التوصيات، من أهمها: الدراسة بمساعدة إدارة المدرسة للمعلمين حديثي التخرج لتطوير مستواهم، وتحفيز المعلمين وإنصافهم في أعمالهم، وإلحاق قادة المدارس في دورات تدريبية 


\begin{abstract}
The present study aimed to identify the extent to which the quality standards of teaching performance in Najran secondary schools have been achieved. It also seeks to identify the quality standards of teaching performance in the official policies of the Saudi school and investigate the criticism and difficulties facing the reality of teaching performance in secondary schools. The analytical descriptive method utilized in this study، where the population consisted of all leaders (principals)، vice-principals and technical supervisors of courses in the public secondary schools for boys in Najran city، the sample numbered (56) leaders (principals) and vice principals and $(\vee \cdot)$ technical educational supervisors. The results showed the role of the school leader (principal) in providing the required training courses for the school administration، and holding special training courses for the fresh graduated teacher and offering national activities in the administrative and educational fields. The results also showed the difficulties and challenges faced by the leader (principal) in the tasks and duties assigned to him outside the school tasks، The most important recommendations are the help of fresh teachers by the school administration to raise their professional level and to motivate teachers who must be treated fairly in their work; the principals should be enrolled in quality training courses .
\end{abstract}




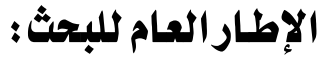

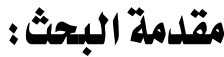

تعد الجودة مفهوماً قديماً، فقد سعى الإنسان في البحث عن أساليب لتطوير كيانه الاجتماعي والاقتصادي، وتأكيا الجودة، وإتقان العمل مبأ إسلامي أصيل؛ حيث ورد في

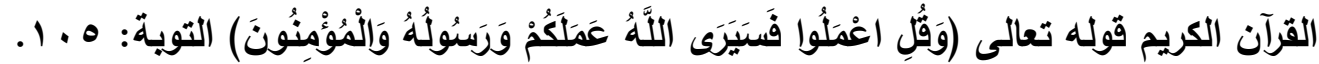
وحظيت الجودة في التعليم باهتمام كبير بوصفها إحدى الركائز الأساسية في تطوير التعليم وتحديثه، فأصبحت الجودة والتظوير وجهين لعملة واحدة، وقد حظيت الجودة الشاملة بجانب كبير من هذا الاهتمام إلى الحد الذي جعل المفكرين يطلقون على هذا العصر عصر الجودة، باعتبارها إحدى الركائز الأساسية لنموذج الإدارة الجديدة الذي تولد لمسايرة المتغيرات الاولية والمحلية، ومحاولة التكيف معها. وتعتمد الجودة مفهوم النظم الأي ينظر إلى المؤسسة بشكل شامل ومتكامل، فيتناول

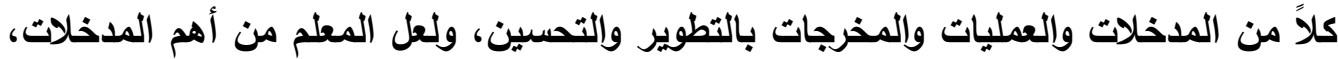
حيث يعتمد عليه بشكل أساسي في تطبيق الجودة في التعليم للحصول على نوعية ذات جودة

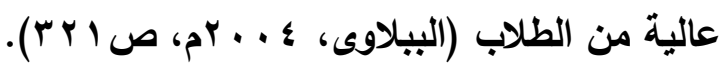

والمتفصص للنظريات المتعلقة بالإدارة المدرسية يجد أن معظمها تضع قائد المدرسة في موقع استراتيجي لكل ما يدور في المدرسة، فهو المسؤول الأول عن نجاح المدرسة

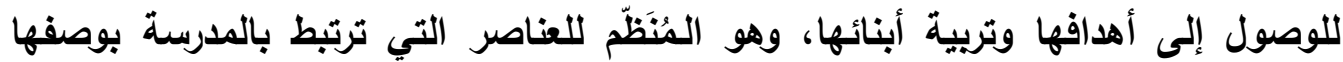

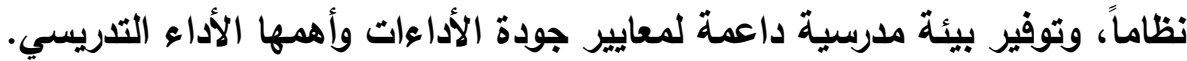
ولتحقيق جودة الأداء التدريسي فإن الدور الجديد للقائد المدرسي يفرض عليه القيام بتطوير دور المعلم ليصبح قائداً وموجهاً لعمليات التعليم والتعلم، وليصبح باحثاً ومحلاً

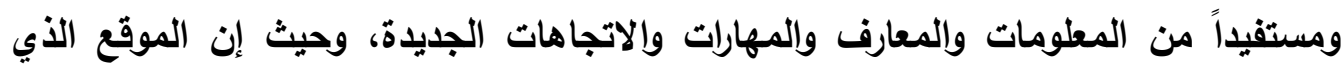
يحتله قائد المدرسة يجعله يرتبط بالمعلمين والعاملين والمستخدمين بالمدرسة من أجل زيادة

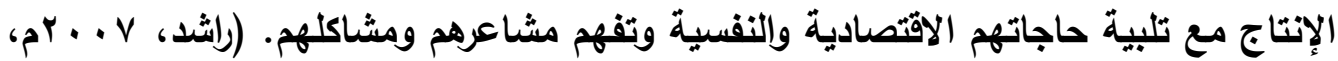


والأدوار الجديدة للمعلم في عصر الجودة تتطلب معايير محددة لمراقبتها وضمان تحققها، حيث تعد هذه المعايير بمنزلة المحك الذي يقاس في ضوئه أداء المعلم، ودليلاً للبعد عن الأتية في الحكم على هذا الأداء، وهذه المعايير تعطي المعلم الحافز للوصول إلى هـئه

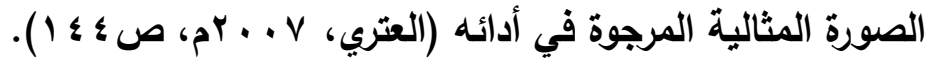
وتجدر الإثارة هنا إلى تعدد المعايير العالمية للجودة الثاملة في أداء المعلمين، ويعود ذلك إلى اختلاف البيئات والثقافات لكل مجتمع، فيتم وضع المعايير بما يناسب ذلك المجتمع، ويحقق أهدافه وتطلعاته، ولذا فإنه لا يوجد نموذج وإحد يكتفى بتطبيقه في مجال معايير الجودة في الأداء التدريسي للمعلم، ولكن توجد العديد من المعايير التي يمكن الاستفادة منها. ولأهمية هذه المعايير في رفع مستوى أداء المعلم أجريت العديد من الدراسات التي

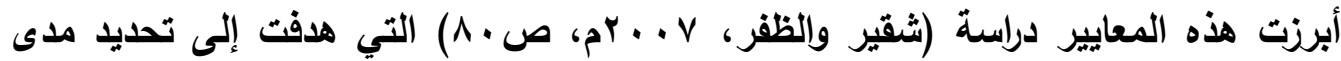
تحقق معايير الجودة لبرنامج التربية الميدانية القائم في كلية الإحساء من وجهات نظر الترات متعددة، ثم وضع تصور مقترح لبرنامج إعداد المعلمات موافقاً لمعايير الجودة والاعتماد الأكاديمي.

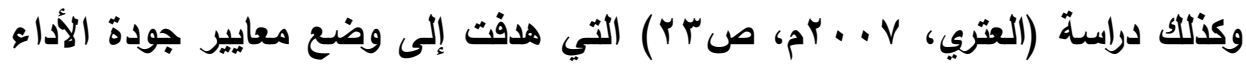
التدريسي، وأوصت الباحثة بتصميم برامج تدريبية للمعلم وفقاً للحاجات التدريبية في ضوء معايير الجودة التي وضعتها الباحثة. وتتجه الدراسة الحالية إلى بحث معايير جودة الأداء التدريسي التي تستغرق كافة أدوار المعلم ومسؤولياته في تصميم المهمات التعليمية، وتيسير الحوار الصفي، وخلق بيئة تعليمية إيجابية، وتثجيع دعم الأقران، والارتقاء بمفهوم التقويم، وغير ذلك من مكونات الأداء التدريسي، ثم كيفية تحقيق هذه المعايير في إطار دور القائد المدرسي، ومن خلال منظومة الإدارة المدرسية.

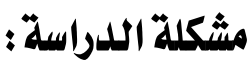
اهتمت وزارة التعليم اهتماماً كبيراً بتلبية الطلب الاجتماعي على التعليم، وافتتاح مزيد من المؤسسات التعليمية، وتوفير الكم المطلوب لها من المعلمين والتجهيزات وموارد البيئة التحتية، إلا أن النمو الكمي الواضح في أعداد التلاميذ والمعلمين والمؤسسات التعليمية لم يُقابل في معظم الأحيان بجودة في الأداء التدريسي، ولاسيما الأداء الذي يتعلق بالعملية 
التعليمية، وهو ما أوضحته نتائج عدد من الدراسات السابقة. من أن هناك أوجه قصور

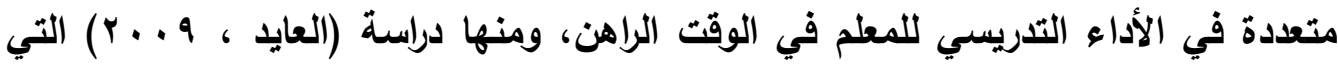
أثشارت إلى تلني مستوى تحصيل طلاب المرحلة المتوسطة في تعلم اللغة الإنجليزية، وأرجع التدني لعدد من الأسباب؛ أبرزها ضعف إعداد المعلم، وعدم تصحيح الأخطاء للطلاب، وكذلك عدم التنويع في طرق التدريس.

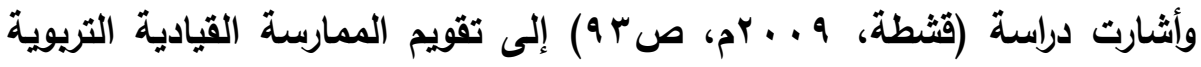
لمديري المدارس الثانوية في ضوء المعايير الإسلامية، وذلك من خلال إشراك المعلمين في اتخاذ القرارات، وتفويض المعلمين بتنفيذ المهام الإدارية والقنية مع المتابعة، والمساهمة في تطوير كفاءة المعلمين من خلال الدورات التدريبية والمساهمة في إيجاد الحلول المناسبة للمشكلات التي تواجه المعلمين قر المستطاع. وإستاداً إلى نتائج الدراسات السابقة ومن ملاحظة واقع الأداء التدريسي في المدرسة الثانوية السعودية، يتضح أن هناك ثمة أوجه قصور تتعكس سلباً على كثير من جوانب العملية التعليمية، التي يمكن وصفها بأنها عملية تقليدية، وأن الأداء التدريسي الراهن لا يستثير في التلميذ قدرات التفكير، التعلم الأتي، والدوافع للإبداع، ويلاحظ أن الأداء التدريسي على هذا النحو لا يتيح فرص توظيف التقتية التعليمية، أو استخدام طرائق تتسم بالحداثة في الوقت الأي تعنى فيه أنظمة التعليم في الدول المتقدة بمفاهيم ومعايير جودة الأداء التدريسي. ولأن الأداء التدريسي يرتبط مباشرة بتحقيق الأهداف المدرسية وينوعية المخرجات التعليمية، تتحتم العناية بسلامة هذا الأداء وجودته من جانب القيادات التربوية، وإلتيقن من مدى قيام هذه القيادات بواجبها لتحقيق معايير جودة الأداء التدريسي، وفهم الثروط والإجراءات المطلوية للوفاء بهذا الدور، ومن هنا فإن مشكلة الدراسة تمحورت حول السؤال الرئيسي التالي: - n ما متطلبات تحسين دور القيادات المدرسية في تحقيق معايير جودة الأداء التدريسي؟ أسئلة الدراسة :

1. ما معايير جودة الأداء التدريسي في الواقع التعليمي للمدرسة الثانوية؟ r. ما الصعويات التي تواجه واقع الأداء التدريسي في المدرسة الثانوية في المملكة العربية 
السعودية ؟

r. ما متطلبات دور القيادات المدرسية والإشرافية للتظلب على تلك الصعويات؟ أهداف الثدراسة : هدف البحث إلى تحقيث الأهداف التالية :

ا ـ تعرف معاييز جودة الأداء التدريسي في الواقع التعليمي للمدرسة الثانوية. r. الكشف عن الصعويات التي تواجه واقع الأداء التدريسي في المدرسة الثانوية. r. تعرف متطلبات دور القيادات المدرسية والإشرافية للتغلب على تلك الصعويات.

أهمية الدراسة:

أ. الأهمبة العلمية (النظرية):

- - تستمد هذه الدراسة أهميتها من خلال تناولها لموضوع يتسم بالحداثة وهو الكشف عن معاييز جودة الأداء التدريسي بما يسهم في تحسين مخرجات المدرسة الثانوية. ب. الأهمية العملية (التطبيقية): - تعيين نتائج الاراسة في تصميم برامج التتمية المهنية للمعلمين على التحو الأي يرفع من كفاعة تلك البرامجج. - تعمل هذه الدراسة على تحديد مدى تطبيق معايير الجودة في الأداء التدريسي في المرحلة الثانوية، والأدوار والممارسات التي تقوم بها القيادات المدرسية لتحقيق معايير الجودة. - ـيؤمل من هذه الدراسة أن تقدم للمسؤولين وأصحاب القرارات في وزارة التعليم وقطاع التعليم العام توصيات تعين في اتخاذ الإجراءات الكفيلة بتحسين واقع الإدارة المدرسية في المملكة العربية السعودية. - - تقدم الدراسة مجموعة من المقترحات والتوصيات لإعانة قادة مدارس المرحلة الثانوية في تحسين أدائهم لاورهم القيادي التربوي.

مصناتحات الثلدراسة: - ماثقيادة التربورية: والقيادة التربوية يمكن تعريفها بأنها: "مجموعة العمليات القيادية التتفيذية والفنية التي تتم عن طريث العمل الجماعي التعاوني الساعي على الاوام إلى توفير المناخ الفكري والنفسي والمادي المناسب الذي يحفز الهمم ويبث الرغبة في العمل الفردي والجماعي النشط والمنظم 
من أجل تذليل الصعاب وتكييف المشكلات الموجودة وتحقيق الأهداف التريوية المحدة

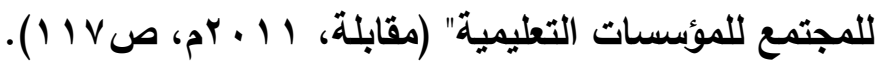
ويعرف الباحث القيادة التريوية إجرائياً بأنها: نشاط أو عمل مشترك تقوم به الجماعة

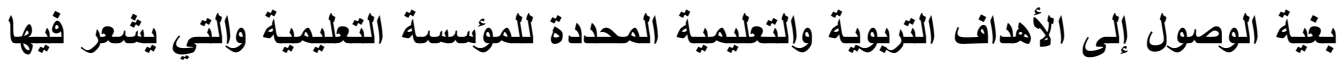
قائد المدرسة بأنه عضو فيها يساعد على تحقيق أهدافها في جو من المودة والتعاون.

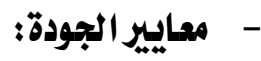

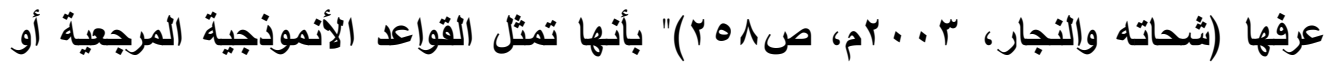
الثروط التي نحكم بوساطتها أو نقيس عليها سلوكيات الأفراد أو الجماعات، والأعمال وأنماط

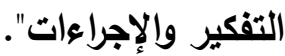
وتعرف معايير الجودة : هي عبارات تصف ما يجب أن يصل اليه المتعلم من معارف ومهارات ويتم في ( النواحي المعرفية ، والمهارية ، والوجدانية) نتيجة لدراسة محتوى كل مجال . - مألاءواء التلدريسي:

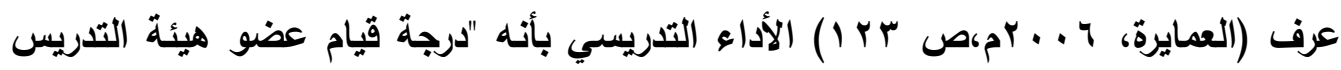
بتنفيذ المهام التعليمية - التعليمية المناطة به وما يبذله من ممارسات وأنثطة وسلوكيات

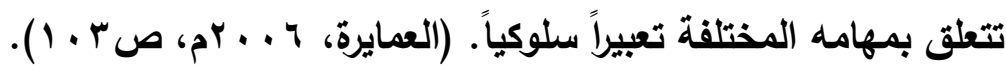

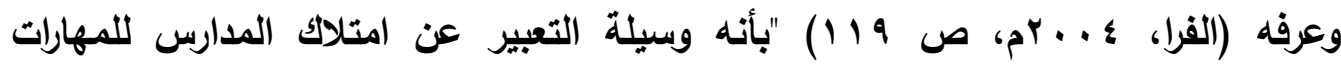
التدريسية تعبيراً سلوكياً".

\section{حدود اللدراسة}

- الحلود البشرية:اقتصرت الدراسة على عينة عشوائية ممثلة للمجتمع تتكون من المشرفين الفنيين للمواد الدراسية والقيادات المدرسية والوكلاء في المدارس الثانوية العامة للبنين في مدينة نجران بالمملكة العربية السعودية. - الحدود المكانية:تركزت الاراسة على مدارس الثانوية العامة للبنين في مدينة نجران بالمملكة العربية السعودية. - الحدود الزمانية: يتم تطبيق الجانب الميداني خلال الفصل الدراسي الثاني من عام

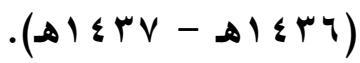
- الحدود الموضوعية:اقتصرت الدراسة الحالية على تناول موضوع تحسين دور القيادات 
التربوية لتحقيق معايير جودة الأداء التدريسي في المدرسة الثانوية (بنين) بمدنية نجران بالمملكة العربية السعودية.

\section{الإطار النظري واللدراسات السابقة}

\section{المحور الأول :الجودة التعليم}

دوافع الاهتمام المعاصر بجودة التعليه:

من الملاحظ أن التركيز على إعداد المعلم إعداداً سليماً للقيام بدوره التدريسي على أكمل وجه هو محور أساس في العديد من المؤتمرات وإلندوات التي تعنى بالمعلم في العالم

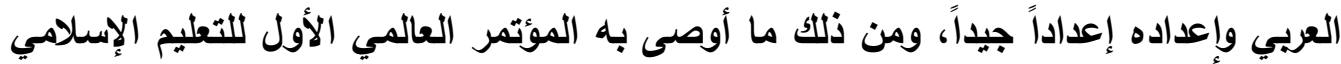

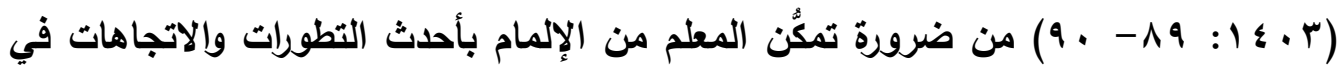
مجال تخصصه، وزيادة مقدرته في تطوير كفايته، وتحسين القدرات المهنية للمعلمين، والعمل على تقويم مدى تقدم المعلم بصفة مستمرة. ويرى (أحمد؛ الحفظي، V . . . م) أن دوافع الاهتمام المعاصر بجودة التعلم تتمثل في ما يلي: عالمية نظام الجودة وكونه سمة من سمات العصر الحديث.

ارتباط الجودة بالإنتاجية وتحسين الإنتاج. اتصاف نظام الجودة بالشمولية في كافة الآلات.

تلدعيم الجودة لتحسين المدرسة. تطوير المهارات القيادية والإدارية.

زيادة العمل وتقليل الههر.

الاستخدام الأمثل للموارد المادية والبشرية.

وجاوت الروية الوطنية للجودة في المملكة العربية السعودية من خلال المؤتمر الوطني

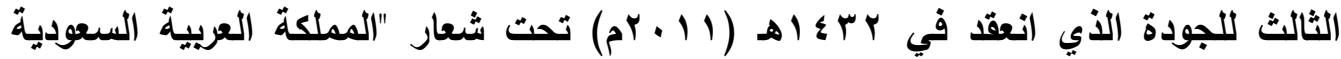

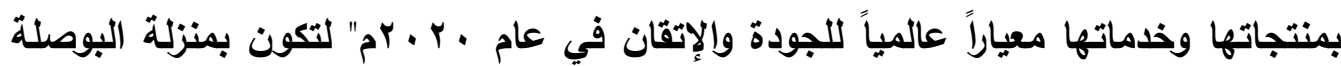
التي ستقود كافة الجهود المبذولة حالياً وتوحدها في مجال الجودة والتميز في مختلف

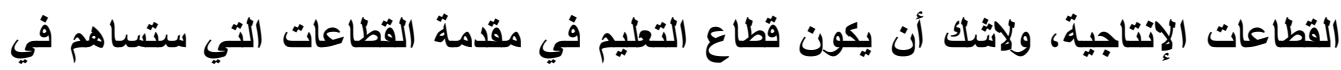
ترجمة هذه الروئة الطموحة وتحقيقها، فهي ترمي إلى الوصول بالمنتجات والخدمات في المملكة العربية السعودية إلى المستوى العالمي لتتمكن من المنافسة وتعزز الاقتصاد الوطني 
والمكانة الإقليمية والدولية لتكون أكبر مصدر للطاقة في العالم، وواحدة من أكبر (·r)

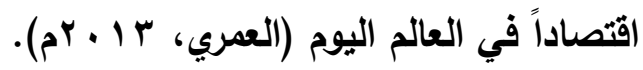

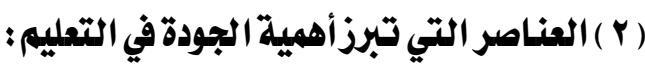
يذكر (البادي، • 1 • Yم) أنه من العناصر التي تبرز أهمية الجودة في التعليم تتلخص في ما يلي: الاهتمام والتركيز على متطلبات المستفيد. المشاركة على كافة المستويات. منهجية قياس النتائج المحققة بالأهداف المحققة. الاقتتاع والدعم من الإدارة العليا. التحسين المستمر .

من هنا تولي الدول المتقدمة أهمية كبيرة لتحقيق الجودة في التعليم ومعايير الاعتماد بسبب قناعتها بأنه يقع على عاتق مؤسسات التعليم المسؤولية الأولى في إعداد أجيالها

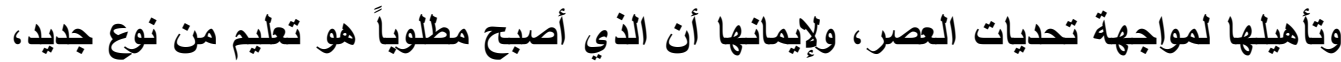
تعليم يهيئ الفرد والمجتمع لحقائق عصر الثورة التكنولوجية والمعرفية التي أصبحت أهم خواص القرن الحادي والعشرين، وهي ثورة تعتمد المعرفة العلمية المتقدمة، والاستخدام الأمثل للمعلومات المتدفقة والمتضاعفة (صبري، 9 ـ . ب م). ومن هنا فإن المعلم أحد أهم عناصر العملية التعليمية وأكثر من يعول عليه فيها، فهو أساس متين وعليه يقع العبء الأكبر في ممارسة الجودة في مهنة التريس من أجل نجاح العملية التعليمية وتحقيق أهدافها، فالأنثطة التي تتم في قاعات الدرس، والواقع الذي يحدثة هئه المعلم وعملية التعليم تمثل متغيرات حاسمة على طريق تحسين نتائج التعليم. فإذا كان المعلم

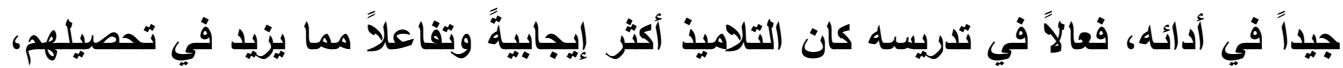
أما إذا كان المعلم خلاف ذلك بحيث يكون سلبياً في أدائه فيزداد بذلك احتمال أن يكون

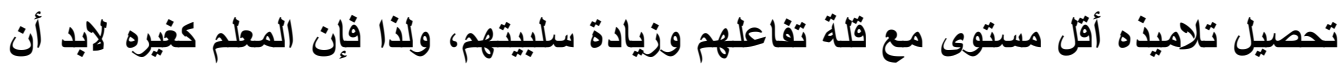
يناله التحسين والتطوير في بيئة التربية والتعليم. 


\section{المحور الثانى : معايير جودة الأداء التلدريسي}

( ) مفهوم الأداء التدريسي:

يعد التعليم في ظل اقتصاد المعرفة من أهم المجالات التي تعمل على إعداد الكوادر

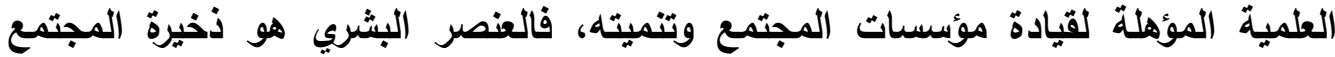
ومصدر الاستثمار الأول فيه، لذلك بات الاهتمام بالتعليم ضرورة حتمية لإعداد أفراد المجتمع فئهي لتقبل التغييرات الجديدة واستمرارها ضمن فلسفة المجتمع، مما استوجب من المؤسسات التريوية الاهتمام بجودة الأداء التدريسي في التعليم لضمان مخرجات تعليمية تؤهل الطلبة

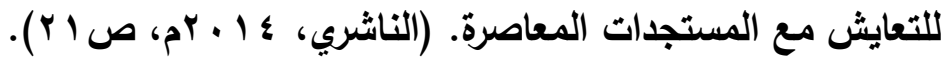

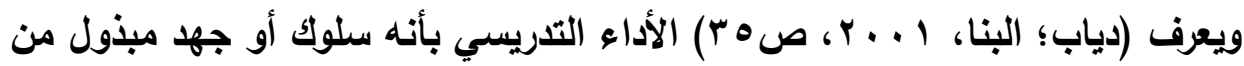
قبل المعلم لتحقيق الأهداف المنشودة وفقاً لمجموعة القواعد والقوانين المنظمة لحملة التخطيط والإعداد، وتنفيذ التتريس، وتقويم الأداء للمتعلمين، وما يرتبط بذلك من مسؤوليات

مهنية.

إن إدراك المعلم لأهمية أدائه التدريسي يجطله على وعي دائم بجواتب القوة ونواحي

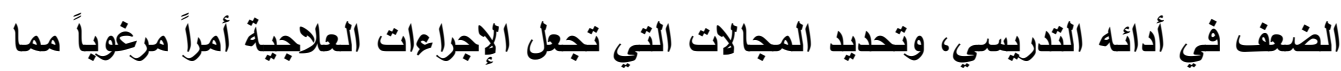

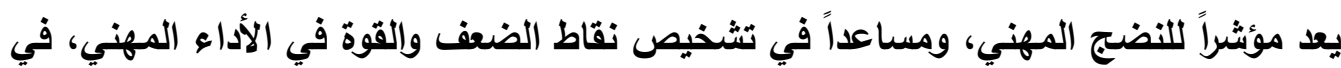
كونها تقوي دافعيتهم نحو العمل وتتيح لهم فرصة لتحقيق الذات في مجال المهنة، وذلك في كونها توفر أداة موضوعية تسمح بالتمييز بين الأفراد عند صرف الأجور التثجيعية أو منح فئح العلاوات والمكافآت، وتسهم في دعم العلاقة بين العاملين والإدارة، وتسهم في اقتراح مجموعة الأن من الوسائل والطرق المناسبة لتطوير بيئته الوظيفية بأساليب علمية ويشكل مستمر (جاد، . وعلى الرغم من تعدد الاتجاهات في النظرة إلى طبيعة العملية التعليمية ووسائل تقييمها،

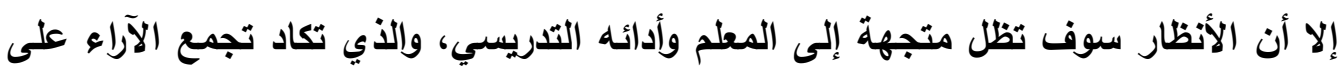

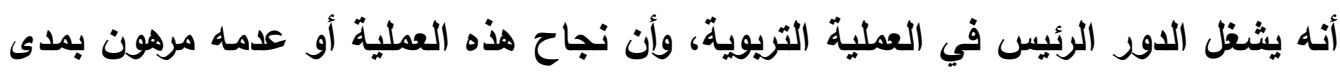

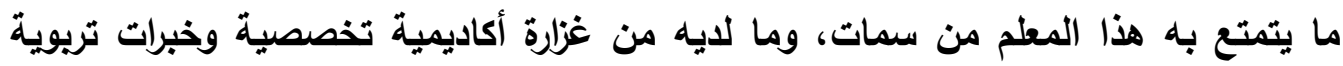


ومهنية، ومن ممارسات سلوكية وثقافية، وعلاقات إنسانية واجتماعية، ولعل الطلبة يمكنهم

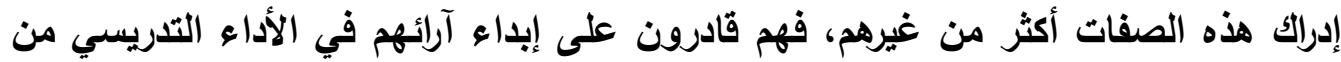
خلال ما يمدونهم به من خبرات تريوية.

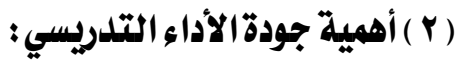

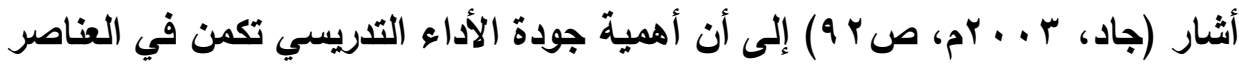

تحسين نوعية التعليم المقدم للتلاميذ بوصفه أحد مكونات العملية التعليمية، وذلك من خلال تحديد نوعية التغيرات المطلوية من المعلم لإمكانية التطوير، أو التحسين المدرسي سواء كانت في طريقة التدريس، أو في بيئة التعلم، أو في مصادر التطليم. تثخيص الاحتياجات الفردية للمعلمين من خلال تحديد كل من جوانب القوة، وجوانب الضعف في الأداء التدريسي، وتوفير التذذية الراجعة التي يمكن من خلالها

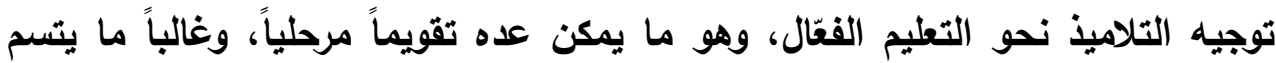
بالوصف أكثر منه حكماً، أو تقويماً للأداء التدريسي. تنمية مهارات المعلم ومعلوماته المهنية لإمكان مساهمته بفاعلية في عمليات التطوير المستقبلية أو التحديث المستمر لمنظومة المنهج المدرسي.

( ) معاييز جودة الأداء التدريسي:

يمكن القول إن ثثافة الجودة في التعليم لا تزال حتى الآن مغيبة في بلادنا العربية، فلا يوجد

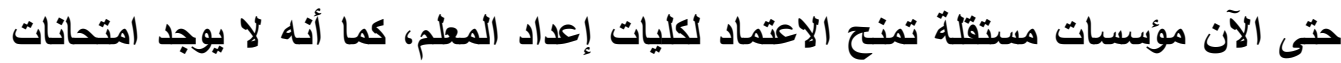
الترخيص أو الإجازة للعمل في المهنة، ويمكن القول إنه من حسن الطالع بأن كليات التربية

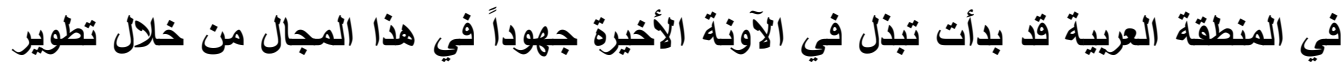

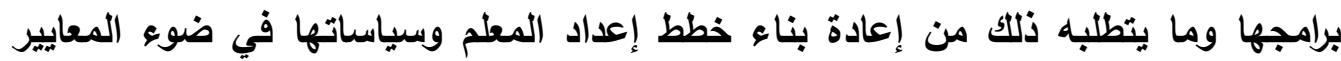
العالمية لتأهيل المعلمين وتربيتهم مما يمكن معه القول إن هذا العمل يمثل نقلة نوعية وكيفية تستهدف الوصول بممارسات المعلم إلى معايير الممارسة المهنية من منظور

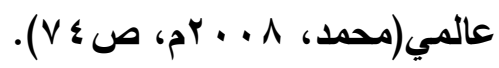
وتحليل الخبرة العالمية في هذا المجال تثير إلى أن معايير جودة الأداء التدريسي المقبول للممارسة المهنية في مجال التعليم تنطلق من النظر إلى المعلم بوصفه ممارساً 
مهنياً، وتتمحور في خمسة مجالات، وهي:

مسؤوليات المعلم عن طلابه وعن تعلمه بحسب أنه مسؤول عن ترسيخ

جهوده لتسيير حصول جميع الطلاب على المعرفة، ومن ثم توجيه ممارساته وتعليلها في ني ضوء ميول الطلاب وقداتهم ومهاراتهم وخلفياتهم بالاستناد إلى فهمه، وكيفية نمو تونه

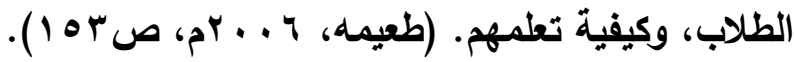

معرفة المعلم للموضوعات والمواد الدراسية التي يتعلمها وكيفية تعليمها للطلاب،

فالمعلم الفعال يتوفر له فهم خصب للموضوعات والمواد التي يقوم على تدريسها، ويمقرته الكثف عن هذه الموضوعات والمواد للطلاب، كما أنه يعني ما يحمله الطلاب معهم من معارف ومدركات ومفاهيم سابقة، وياستطاعته إبداع مسارات معرفية متعددة تتناسب وتباين طلابه وأخلاقهم، ويسعى لتعليمهم كيف يحدادون مشكلاتهم ويطرحونها، وييحثون عن حلول لها.

مسؤوليات المعلم عن إدارة تطم الطلاب ومراقبتهم، فالمطلم المهني مسؤول عن

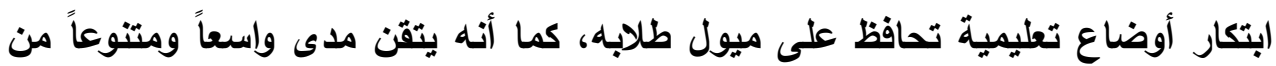

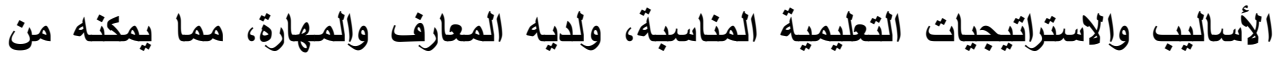
التوظيف الفعال لها في الوقت المناسب لاستثارة دوافع طلابه ودمجهم فرادى وجماعات

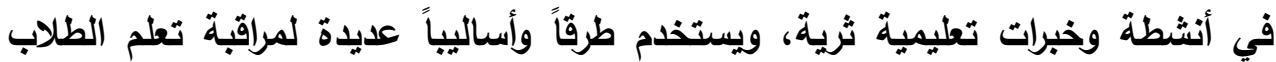
وقياس نموهم وشرح أداء الطالب وتفسيره لوالديه. القدرة على التفكير بطريقة منظمة في ممارسات التعلم والنمو المهني من خلال

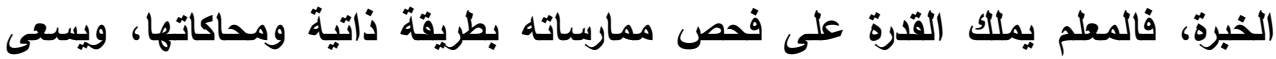
للحصول على مشورة الآخرين ونصحهم، والإفادة من البحث التريوي لتسيق معارفه

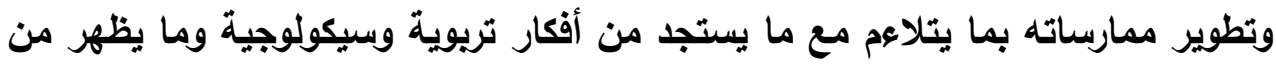
مكتشفات علمية وتكنولوجية. الانخراط بثكل عضوي في مجتمعات التعلم، فالمعلم المهني يمارس عمله على آلى إنى نحو تعاوني مع آباء الطلاب ويشكرهم في العمل المعلي ويسعى لاستثمار إمكانيات المعلم والمجتمع المحلي ومصادره المختلفة في إثراء تعلم الطلاب. وقد عنيت الأدبيات بتفعيل معايير جودة الأداء التدريسي، وشروط تحقيقها تبعاً لهذه 
تحسين دور القيادات التربوية لتحقيق معايير جودة الأداء التدريسي....

المجالات آنفة الأكر. 


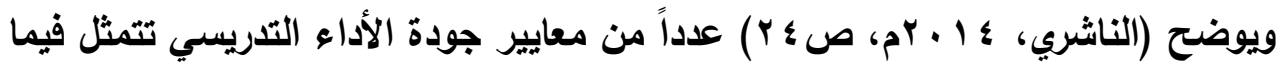
يلي:

القيادة: وتمثل الإدارة العليا ونظام القيادة والتنظيم، ومسؤولية المجتمع والمواطنة.

المعلومات والتحليل : وتتمثل بإدارة المعلومات والبيانات والمقارنة بين المعلومات،

وتحليل مستويات التحصيل الدرسبي واستخدامها.

التخطيط الإجرائي والتخطيط الاستراتيجي: وتثثمل التطوير الاستراتيجي وتنفيذ

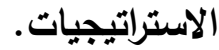

إدارة القوى البشرية وتطويرها: وتتمثل في تقويم القوى العاملة وتخطيطها،

ونظام تثغيل الهيئة التدريسية، ونظام تطوير الهيئة التدريسية، والرضا المهني للهيئة

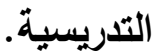

الإدارة التربوية: وتثثمل تصميم النظام التربوي، والخدمات التعليمية، ودعمها،

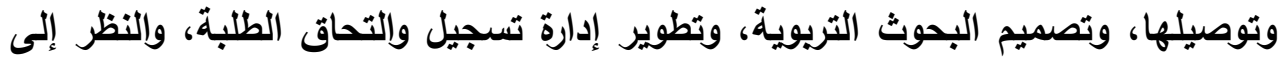

الإدارة التريوية على أنها عمل اقتصادي.

أداء المدارس وتتائج الطلبة: وتشمل نتائج الطلبة، والمناخ المدرسي وتحسين

المناخ المدرسي والنتائج، والأبحاث في مجال أداء المدارس، والنظر إلى أداء المدارس على أنه عمل اقتصادي.

رضا الطلبة وممولي النظام التربوي: وتثثمل حاجات الطلبة الحالية والمستقبلية، والعلاقة بين ممولي النظام التعليمي والإدارة التريوية، ورضا الطلبة وممولي النظام التعليمي الحالي والمتوقع، ومقارنته مع باقي المدارس أو النظم التربوية الأخرى.

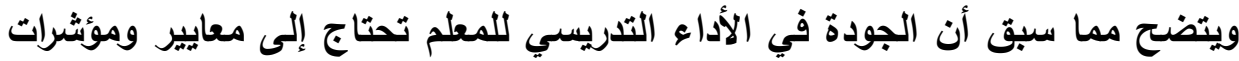
لملاحظتها وضمان تحققها في أدائه، وتكون هذه المعايير بمنزلة دلالات على مستوى أداء

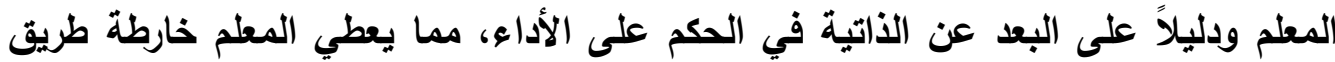

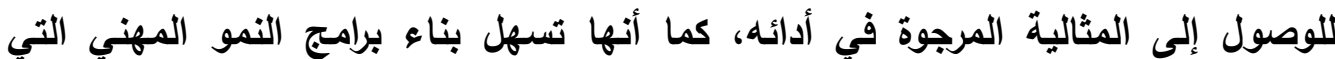


تحسين دور القيادات التربوية لتحقيق معايير جودة الأداء الثدريسي.

يحتاجها سواء أكانت من قبل المؤسسة التعليمية أو من قبل المعلم نفسه. لذلك تسعى النظم التعليمية إلى تنمية المعلم ورفع جودة أدائه التدريسي من خلال تركيزها على المحتوى وتكامله مع أسلوب التدريس بهدف خلق بيئة تعلم فعالة ومغذية لتمبه بالإمكانيات التكنولوجية ومراعية للفروق الفردية لتحقيق أهداف العملية التعليمية. 
ونظراً لأهمية الدور الذى يلعبه المعلم، تنبهت القيادات المدرسية لهذا الدور من خلال السعي المتواصل لتحسين الأداء التدريسي والمهني له. فحرصت على أن تتوفر في معلميها الكفايات المأمولة للقيام بهذا الدور، فهي تتوقع من المعلم أن يكون ذا قدرات، وخصائص متميزة

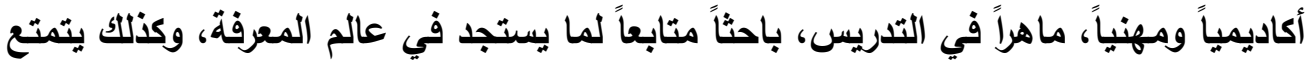
المعلم الفاعل برؤى تطويرية يؤكد فيها ذاته، ويشجع طلبته على تأكيا ذواتهم عبر ممارسة التأمل في التعليم، وتعزيز التفاعل بهدف إيجاد تحول نوعي في تعليمهر. (r ) مجالات المعايير التي يجب أن يتقنها المعلم: في دراسة (Leib, 2010) حدت مجالات المعايير التي يجب أن يتقتها المعلم فيما

المجال الأول: مجال التخطيط (الطويل والمتوسط واليومي). المجال الثاني: مجال التدريس (تنويع الاستراتيجيات ومعرفة توقعات المتعلم وإمداده بالمحتوى المناسب وإثارة الدافعية وتنويع سبل التعزيز). المجال الثالث: مجال بيئة التعلم من حيث تحقيق المواصفات التي تجعل التعلم نشطاً والتقاعل موجهاً لتحقيق الأهداف). المجال الرابع: مجال الاحتراف، وقد حدد في قدرة المعلم على أن: - - يحدد احتياجات المتعلمين بدقة؛ أي يعرف ماذا يحتاج وما الذي يكون قادراً بالفعل على الفي عمله. - - تصميم مواقف التعلم لكي يصبح التعلم ذا معنى للمتعلم. - - يحلل أداء المتعلمين ليعرف مدى تقدمهم في التعلم. - - يستخدم نتائج التحليل السابقة في التخطيط المستقبلي. - ـ يقوم مدى استفادة المتعلمين من المعلومات والمهارات التي حصلوها في مواقف الحياة. 
المحور الثالث : دور القائل التربوي في تحقيق جودة الأداء التدريسي : (1 ) الخصائص العامة للقيادة التربوية الناجحة:

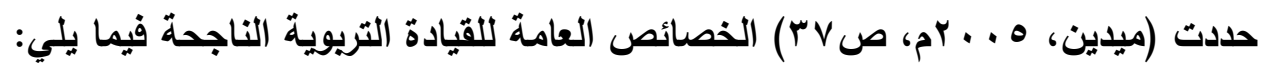

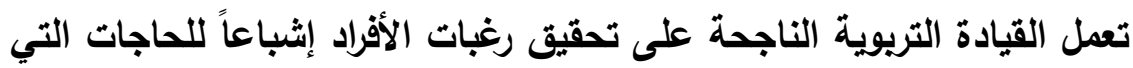
تظهر في الجماعة.

تحاول القيادة التريوية الناجحة الانتفاع من ضرورة البواعث الذاتية والحوافز الداخلية للنشاط في كل فرد من أفراد الجماعة.

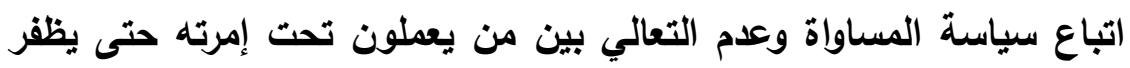
باحترام جماعته أو يرتفع في أعينهم. ولعل من أبرز إجراءات تحقيق النجاح للقائد التريوي ما يلي (الحربي،

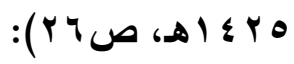

التخطيط للأهداف التريوية القريبة المدى والبعيدة المدى وللعملية التريوية حيث تكون الأهداف واقعية ممكنة التحقيق. الإدارة والتنفيذ وتحريك التفاعل لتنفيذ السياسة والمناهج وتحقيق الأهداف بإيجابية.

صيانة بناء الجماعة من حيث علاقات الود والتجاذب والتعاون وطرق الاتصال بين الأعضاء وإمكانات الحراك الرأسي والأفقي.

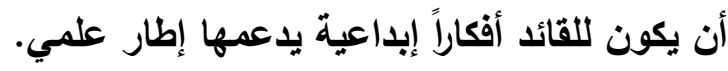

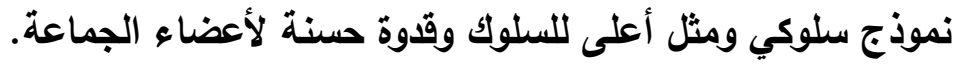
رمز للجماعة واستمرارها في أداء مهمتها.

محافظ على الجماعة وتيسير القوى التي تجذب الأعضاء للجماعة.

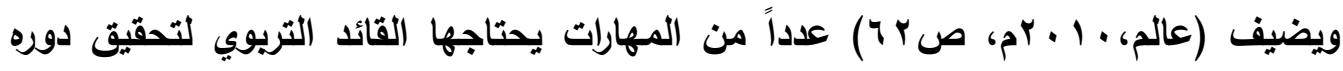

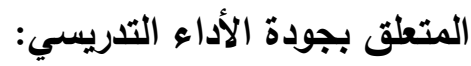
التأثير على مرؤوسيه واستخذام الوسائل من أجل تحفيزهم على العمل والإنتاج، ومن هذه الوسائل الخبرة الثخصية للقائد. 
توجيه المرؤوسين، وتوحيا جهودهم، والتتسيق بينهم في توزيع مسؤوليات

العمل بناءً على تخصصاتهم وقراتهم وإمكانياتهم وخبراتهم واهتماماتهم الشخصية.

تحقيق الهدف الوظيفي المتمثل في تحقيق أهداف المدرسة الذي يسعى جميع

العاملين بها لبلوغها.

(r ) دور القائد التربوي في تحقيق جودة الأداء التدريسي:

القيادة التريوية الفعالة هي صمام التجاح لكل مؤسسة تريوية، وتعد قيادة تعاونية

فعالة إذا اسنطاعت خلق روئة تريوية واضحة مع تهيئة المناخ المناسب للوصول إلى أعلى هوسئ نرئه مستوى من الإنجاز، مع قدرتها على الاتصال المباشر مع جميع العاملين في المؤسسة التريوية، وتزداد فعالية القيادة التريوية بما لايها من القوة على استقطاب الكفايات لتعزيز قدرات المؤسسة التريوية.

ويمارس قائد المدرسة دوراً قيادياً في مدرسته من حيث التظيم، والتخطيط، والتنسيق، والتفويض، لذا فإن عليه أن يحافظ على انفتاح وإعٍ في التعامل مع مصادر المعلومات، وأن يكون محفزاً وموجهاً للجهات واللجان واللهيئات التي تضمها المدرسة. ولابد من أن ينطلق قائد المدرسة من دراية معرفية، ويكون لايه اتجاهات إيجابية نحو

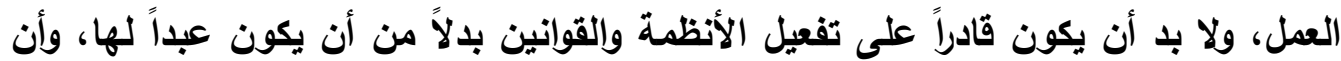

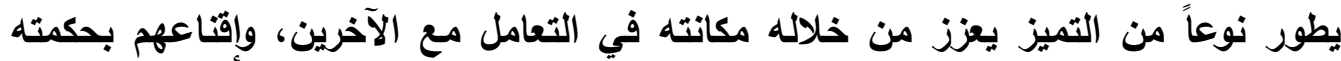
وإدارته، ودرايته، وأن يؤمن بأن أي إصلاح تريوي يتطلب وقتاً لتصحيحه، وتنفيذه، وتجسيده، وأن الأمور لا تتم بالتسرع، أو القفزات المفاجئة غير المدروسة، وإنما بانية بالتدرج، وإلمرحلية

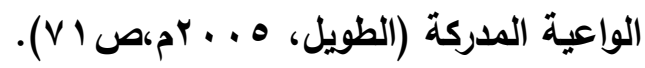

وإن نجاح القيادات التريوية في مهمتها يعتمد على النمط الإداري والقيادي الذي تتبعه

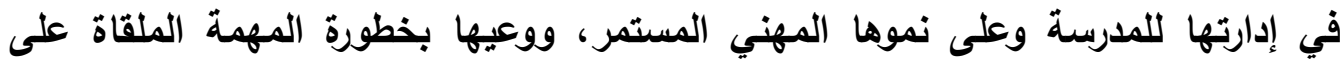
عاتقها، وميلها للتجديد، والتطوير، والإبداع في مجال العمل.

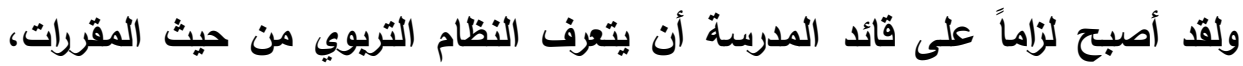

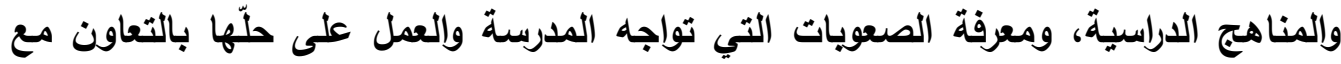

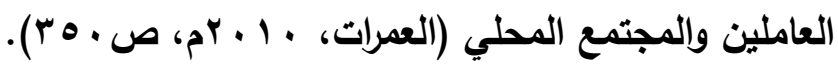
ولابد لقائد المدرسة من أن يمتلك روئيا وإحة؛ لأن هذه الروئا تعطيه القوة، والثقة، 
وتساهم في إقتاع الآخرين على العمل، حيث إن مدير المدرسة يحدث تغييراً إيجابياً في

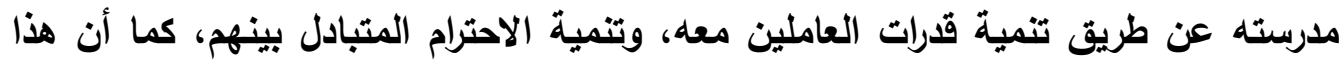
التغيير الإيجابي في مدرسته لا يحدث ما لم يقم بدعم العاملين والمعلمين، وإثشاعة جو نفسي ملهي مريح، يؤمن بمبدأ العمل التعاوني والجماعي. وإن أهم ما يميز المدارس الفعالة الإدارة المدرسية الكفؤة والمتفهمة لدورها، والثقة

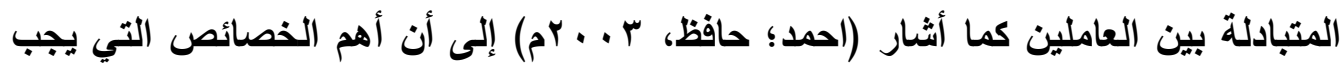
أن تتمتع بها الإدارة المدرسية الفاعلة أن تكون إدارة هادفة وموضوعية في قراراتها، وإيجابية في حل مشكلاتها.

ويعد تحقيق جودة الأداء التدريسي من أهم الموضوعات الحساسة التي تثير اهتمام القيادات التربوية لما لها من آثار إيجابية على العلية التعليمية بصفة عامة، والمرحلة الثانوية بصفة خاصة، ومن هنا فإنه من الضروري وضع روئا مشتركة عن الأداء المتوقع بين القائد التريوي والعاملين بالمدرسة من خلال الوصف الوظيفي لمعايير الأداء والأهداف المحددة، ودعم القائد التريوي وتحفيزه للقيام بأدواره ووضع البرامج التدريبية التي من شأنها المساهمة الفاعلة بقيام القائد التربوي بأدواره الإيجابية في تحقيق الأداء التدريسي. بادئ

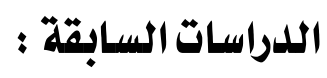

المحور الأول : دراسات تناولت دور القائد التربوي في إدارة العملية التعليمية: 1 - دراسة عماشة ( ) أاه ) وعنوانها : "معايير الجودة في مدارس التعليم العام" هدفت الدراسة إلى إعداد معيار لتقييه الكفاءات المهنية للمعلم في ضوء معايير الجودة الشاملة من وجهة نظر مستقبلي الخدمة من الطلاب والطالبات في التخصصات المختلفة"، ومعرفة أكثر الكفاعات المهنية ممارسة لاى المعلم، وكانت أداة الدراسة بطاقة تقييم أداء معلمة حددت فيها الباحثة الكفاعات المهنية المطلوية وعددها ( •0) كفاية مهنية، موزعة على (V) محاور أساسية، واقترحت الباحثة أن تكون عينة الاراسة مكونة من ثلاث فئات: المعلمين، القائمين على شؤون تقييم المعلم من مديرين ومشرفين تريويين، طالبات المرحلة الثانوية القادرات على تقييم أداء المعلمين. ومن أهم نتائج الدراسة: التوصل إلى إعداد قائمة بالمعايير التي يمكن أن تستخدم من قبل الطالب أو المقوم، لتكون معايير الجودة الثاملة التي يقَيم في ضوئها المعلم في المجال التعليمي بمراحل التعليم العام. 
r - دراسة، العتيبي ( V•rم ) وعنوانها : "تصور مقترح لدور الإدارة الملدرسية في تحقيق معايير الجودة التعليمية بعلارس الثانوية العامة للبنين بمكة المكرمة" هدفت الدراسة إلى معرفة واقع ممارسة الإدارة المدرسية لأهدافها وأنماطها وأهم المشكلات التي تواجهها، وتعرف أسس إدارة الجودة ومراحلها وأهم مداخلها، ثم محاولة الوصول لتصور مقترح لتحقيق دور الإدارة المدرسية الثانوية في رفع الجودة التعليمية وتطويرها، واستخدم الباحث المنهج الوصفي التحليلي، وقد الته استخدمت الاستبانة كأداة لجمع البيانات، وتم توزيعها على عينة من معلمي مدارس المرحلة

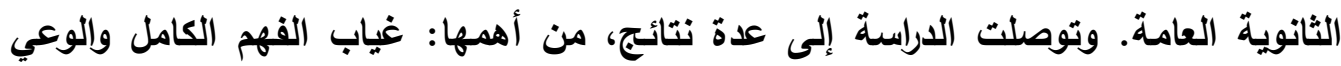
لمعنى الجودة الثاملة وأهدافها، ومسؤولية كل من يعمل في المدرسة عن المشاركة في

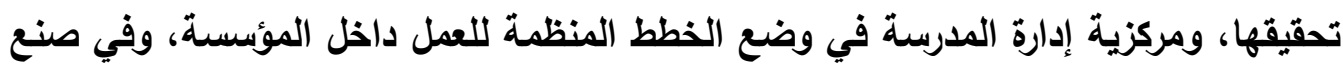
القرارات بالمدرسة واتخاذها، وتدني مستوى الإمكانات المادية والتجهيزات المتاحة بالمدرسة والكوادر البشرية المدربة للعمل على تحقيق أهداف العملية التعليمية. r- دراسة البكر ( ا.+rم ) وعنواثها : "أسس ومعايير نظام الجودة الشاملة في المؤسسات التربوية والتعليمية"، وهدفت إلى وضع إطار منهجي للدعم وتقويم مسار الجودة في العملية التعليمية، وذلك من خلال تطبيق المواصفة الدولية للجودة ( الأيزو r.+9 ) في مجال التربية والتعليم وتوظيفها، وتطبيق عناصرها كمعايير لعملية تقويم مستوى وفاعلية جودة الأداء في المؤسسات التربوية والتعليمية وقياسها، وقد اعتمد الباحث في منهج الدراسة على بعدين رئيسين هما: التحليل والتطبيق. ومن أهم النتائج التي توصل إليها: ضرورة الأخذ بمعايير المواصفة الدولية للجودة في بنية لهية التعليم ونظامه، وأهمية الأخذ بتطبيقات المواصفة الدولية للجودة في مراحل التعليم المختلفة. والإسهام في بلورة إطار متكامل للمواصفة الدولية للجودة في مجال التربية. المحور الثاني : دراسات تناولت دور القائد الملدرسي في تحقيق معايير جودة الأداء التدريسي: ا- دراسة، الناشري (عا•rم) وعنوانها: "جودة الأداء التدريسي لمعلمي الدراسات الاجتماعية والوطنية بـالمرحلة المتوسطة في ضوء متطلبات اقتصاد المعرفة"، وقد هدفت الدراسة إلى الكثف

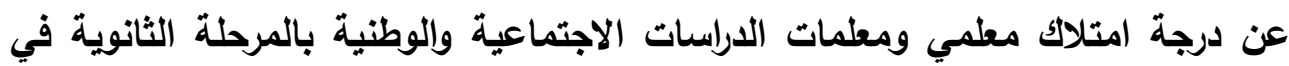
المملكة العربية السعودية لمتطلبات جودة الأداء التدريسي في ضوء التوجه نحو اقتصاد 


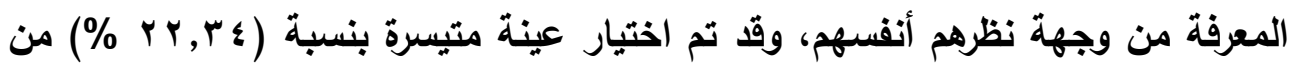
مجتمع الاراسة، ويشكل يتناسب مع متغيرات الدراسة، إذ بلغ حجم العينة (ه V \& ) معلماً

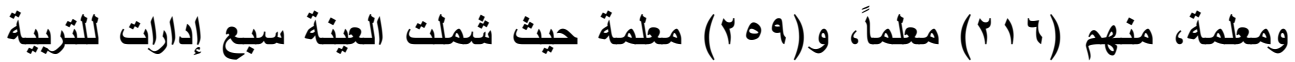
والتعليم في المملكة، واستخدم الباحث المنهج الوصفي التحليلي، كما استخدمت الدراسة الاستبانة كأداة لجمع البيانات تكونت من(ه) مجالات واشتملت هذه المجالات الخمسة على (ال) فقرة، وأظهرت نتائج الاراسة أن امتلاك أفراد العينة لمتطلبات جودة الأداء التدريسي في ضوء التوجه نحو اقتصاد المعرفة جاء بدرجة متوسطة، وكثفت الدراسة

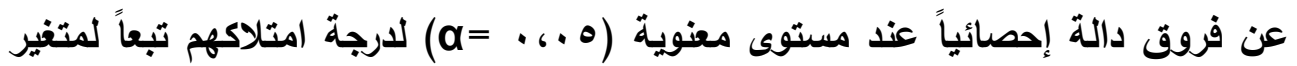
النوع الاجتماعي لصالح المعلمات.

r - دراسة، المزمومي ( •l-rم ) وعنوانها : "مستوى أهمية وتطبيق بعض معايير الجودة الشاملة في برامج تدريب المشرفين التربويسين بمراكز التدريب التزبوي بملينة مكة المكرمة"، واستهدفت الدراسة تحديد أبرز معايير الجودة الثاملة الواجب توفرها في البرامج التدريبية للمشرفة التريوية في تخطيط البرامج التدريبية وتنفيذها وتقويمها، وتعرف مستوى تطبيق بعض معايير الجودة الثاملة في تخطيط البرامج التدريبية للمشرفة التريوية، وتنفيذها، وتقويمها، واستخدم الباحث المنهج الوصفي، وتكون مجتمع الدراسة النهائية من

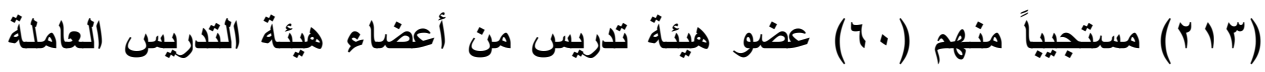
بكلية التربية بجامعة أم القرى و(1 1 1 ) مشرفاً تريوياً يعملون بمكاتب التربية والتعليم

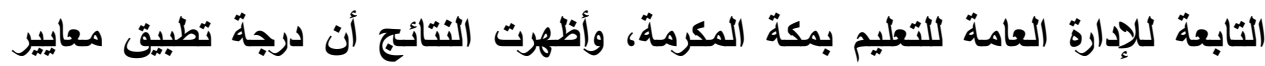

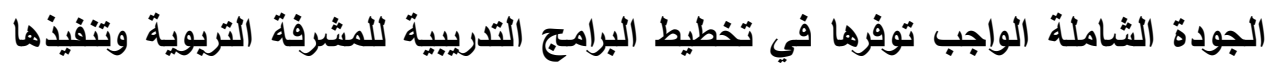
وتقويمها في مراكز التدريب التربوي جاعت بلرجة متوسطة.

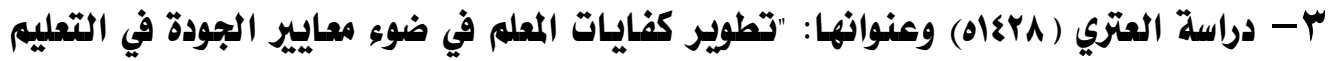
العام"، وهدفت الدراسة إلى التعرف على مفهوم الجودة في مجال التعليم العام، وإلتعرف على الجوانب المختلفة لدور المعلم في ضوء معايير الجودة في النظام التعليمي العام،

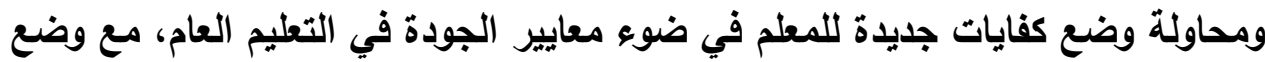
روئيا لإكساب المعلم الكفايات اللازمة في ضوء معايير الجودة في التعليم العام. وقد اتخذت الباحثة منهج التحليل النفسي لتحليل دور المعلم في ضوء تحديات الألفية الثالثة 
ومفهوم الجودة واستتباط معايير الجودة منها، ووضع كفايات يكتسبها المعلم من خلال إعداده أو تدريبه أو من خلال الدورات التدريبية أثناء الخدمة. ومن أهم نتائج هذه هنه الدراسة: مفهوم الجودة في مجال التعليم ليس تعبيراً جديداً، فقد حث ديننا الإسلامي الحنيف على إجادة العمل وإتقانه، والتوصل إلى تحديد معايير الجودة في أداء المعلم في كل جانب من الجوانب المختلفة لاور المعلم في الألفية الثالثة في التعليم العام. ع - دراسة، الفاملي ( ץ.•rم ) وعنوانها : "تصور مقترح لتطبيق نظام الجودة الشاملة في المؤسسات التربوية والتعليمية السعودية في ضوي المواصفة اللدولية للجودة"، وقد هدفت الدراسة إلى تعرف مفهوم إدارة الجودة الثاملة في التعليم وأهميتها في حقل التعليم التريوي، ومتطلبات تطبيق الجودة الشاملة في التربية والتعليم، ومؤشرات تطوير الأداء نحو تطبيق الجودة الثاملة في التربية والتعليم، والأخطاء الشائعة المتوقعة عند تطبيق الجودة الشاملة في التربية والتعليم، والمعوقات والمشكلات التي تؤدي إلى ضعف المخرجات من التعليم العام، وضعف في المدخلات للجامعات السعودية، واعتمدت الدراسة المنهج الوصفي، واتبعت الدراسة في جملتها الأسلوب التحليلي التركيبي النظري كطريقة للتعرف في الجانب الأول على طبيعة إدارة الجودة الشاملة من حيث مفهومها

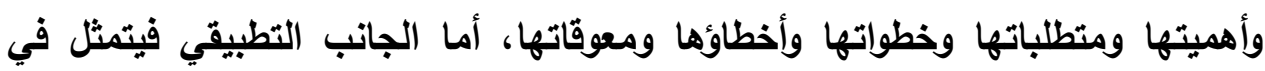
وضع تصور مقترح لتطبيق نظام الجودة الثاملة في المؤسسات التريوية والتعليمية

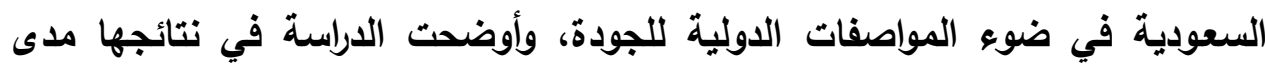

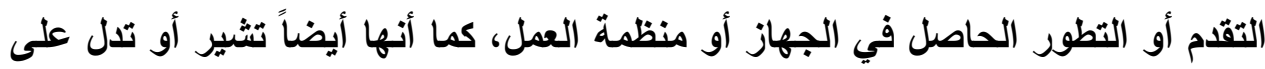
مدى الانحراف أو القصور في أداء الجهاز أو العاملين.

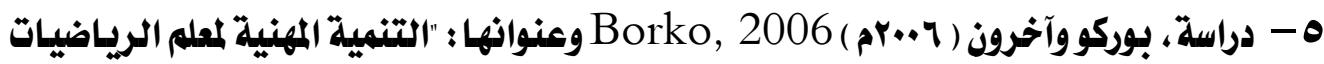
في ضوي تنمية الأككاروالتدريبات المرتبطة بـالتقييم الأدائي في اختبارات الريـاضيات والنجاح فيها"، واستهدفت الدراسة التركيز على عمليات التغيير التي حدثت لمجموعة من معلمي الصف الثالث في مرحلة التعليم الأساسي، من خلال الاهتمام بالعوامل التي أدت إلى منى ملى التغيير والمتغيرات الفاعلة في عملية التعلم التي مرت بها مجموعة المعلمين أثناء مشاركتهم في مشروع التقييم التابع لجامعة كولورادو، والتي استهذفت مساعدة هؤلاء

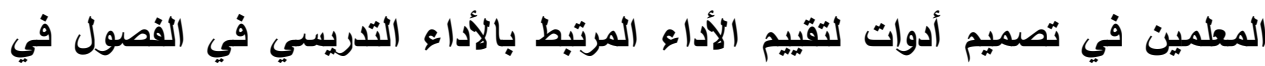


الرياضيات، وتمت مساعدتهم في تصميم الأدوات واستخدامها وفقاً لما يتم تدريسه في الفصول، واستخدمت الدراسة الأسلوب الكيفي في البحث؛ حيث تم جمع البيانات من خلال ورش العمل واللقاءات والأحاديث مع المعلمين في بداية العام ومنتصف العام ونهاية العام لجمع البيانات ومعرفة العوامل التي أدت إلى ذلك، وأظهرت نتائج الدراسة أن عملية التغيير تحدث خلال التدريب والاستخدام المستمر والممارسة في الموقف التعليمي، والمناقشات الجماعية تؤدي إلى نمو المهارات الاجتماعية وينائها، والنمو المهني العام يتيح فرصاً أفضل لنمو الأفكار الجديدة المبنية على الفهم والاستيعاب لاهتمامات الآخر، والتوافق القيمي والعقائدي مع فكر المعلمين يسهم في إحداث التغيير، ودون ذلك ريما يؤدي إلى نتائج عكسية، وحسن إدارة الوقت من أهم العناصر الفاعلة في التغيير. צ- دراسة، فضل الله وسالم ( 0•rم ) وعنوانها : "معايير مقترحة لأداء معلمي اللفة العربية بـالتعليم العام"، وقد استهدفت وضع معايير لأداء معلمي اللغة العربية بالتعليم العام، تقدم بوصفها مقترحاً، يمكن بعد مناقشته، وتطويره، والوصول به إلى المستوى المنشود

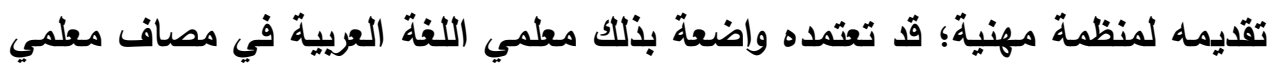

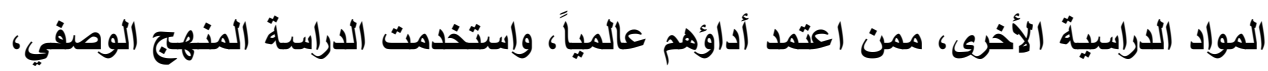
وقد قام الباحثان بإعداد قائمة بالمعايير المقترحة لأداء معلمي اللغة العربية بالتعليم

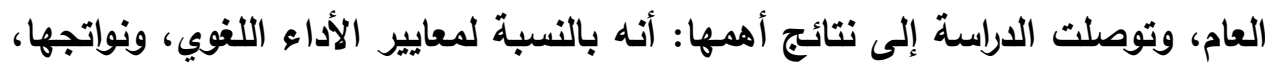
ومؤثراتها تحدد للأداء اللغوي ثلاثة مجالات هي مجال: مهارات الاتصال اللغوي، مجال

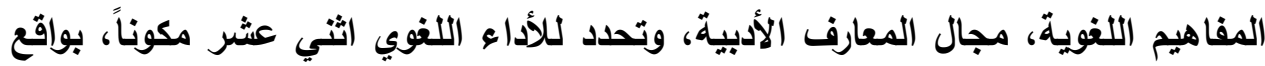
أربعة مكونات لكل مجال، وتحدد لكل ناتج عشرة مؤشرات للأداء، بلغت في مجموعها مئة وعشرين أداء لغوياً، تقدم أدلة فعلية على قدرة معلم اللغة العربية على استخدام اللغة العربية. -V دراسة مارلات (§.•rمa ) Marlatt (2004) وعنوانها : "خصائص مليري التربية والتعليه اللذين يعلون قادة تعليميين فاعلين"، استهدفت هذه الدراسة تحديد خصائص مديري التربية والتعليم الذين يعدون قادة ناجحين في ولاية كاليفورنيا وذلك من خلال تحليل الأساليب والاستراتيجيات التي يستخدمونها لرفع المستوى وتثجيع الأعضاء وتقديم المساندة لكل 
الأطراف، وصولاً إلى تحديد الاستراتيجيات التي يستخدمها مديرو التربية والتعليم الذين يعدون قادة تعليميين فاعلين. وقد استخدمت المقابلة كأداة لجمع البيانات، حيث تم إجراء مقابلات شخصية مع مديري التربية والتعليم، والمسؤولين في خمس إدارات

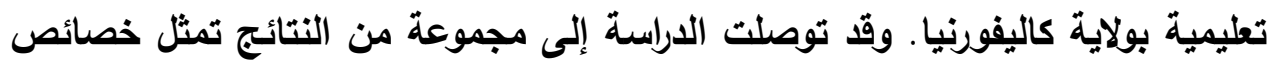

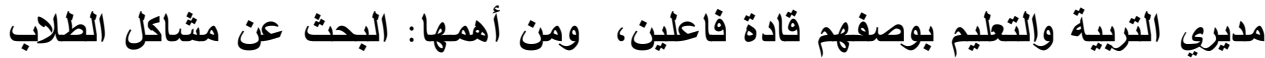
الحقيقية من أجل مساعدتهم على النجاح في الحياة، والرغبة في المحافظة على مناصبهم من أجل ترك ميراث من النجاح، العمل على تأسيس نظم اتصال فعالة تنتشر في المجتمع التعليمي من اجني

\section{التعليق على اللدراسات السابقة :}

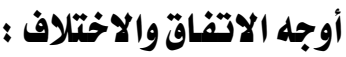

جاعت هذه الدراسة لتتفق إلى حد كبير مع بعض الدراسات السابقة من حيث جودة

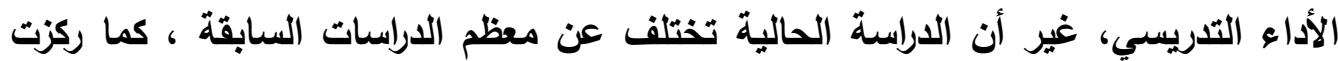
الدراسة الحالية على تحسين دور القائد المدرسي في مجال تحقيق معايير جودة التدريسي في

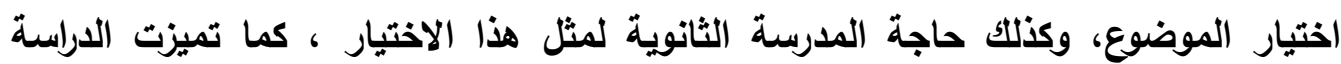
الحالية كذلك بشمولالنظر الى القيادة المدرسية على انهامجموعة القيادات الادارية والاشرافية .وياتي ذلك من منطلق الدور القيادي لكليهما حيال تحقيق معايير جودة الاداء التدريسي،

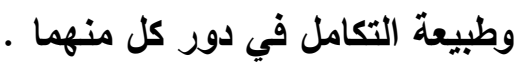
أوجه الاستفادة من الدراسات السابقة: استفادة الدراسة الحالية من الدراسات السابقة في موضوع الدراسة حيث جاعت الدراسة

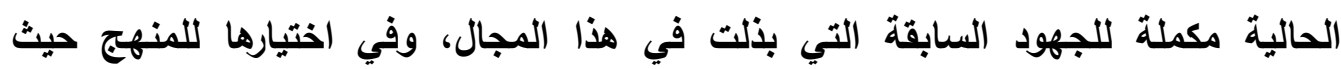

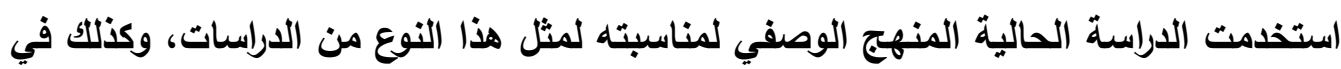
تحديد المتفيرات والإجراءات المناسبة وهو المنهج الذى استخدمته الدراسات السابقة، ويناء أداة الاراسة، وإثراء الإطار النظري لدراسته الحالية بجملة من الموضوعات. منهجية البحث وإجراءاته

منهج الدراسةة : - ماسة

قام الباحث باتباع المنهج الوصفي التحليلي الذي يعتمد دراسة الواقع أو الظاهرة كما 


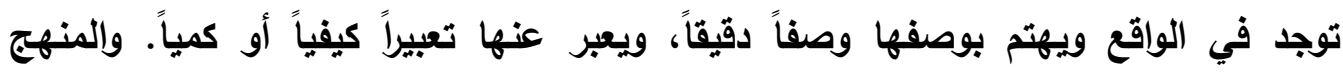

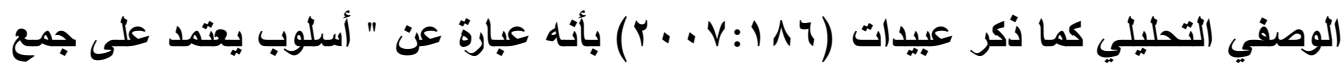

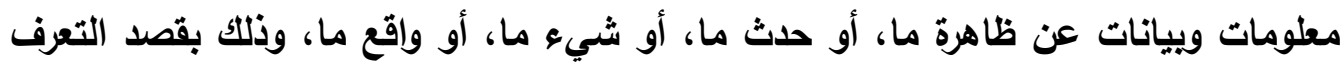
على الظاهرة الددروسة، وتحديد الوضع الحالي لها، والتعرف على جوانب القوة والضعف فيه

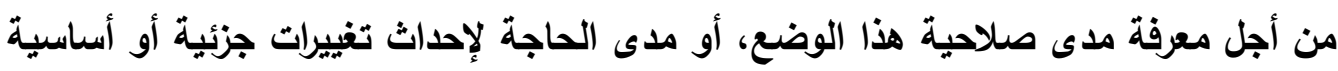
فيه.

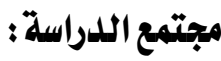

يُعرَفَ مجتمع الدراسة بأنه "جميع مفردات الظاهرة التي يدرسها الباحث، ويذلك فإن إنان

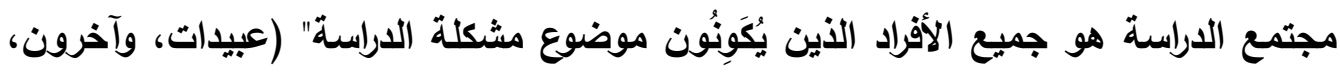

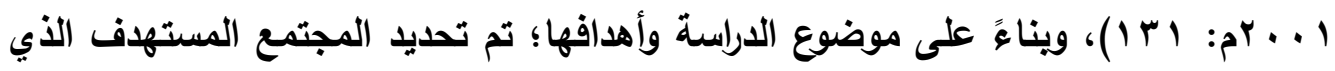
يتكون من جميع المشرفين للمواد الدراسية كذلك القيادات المدرسية والوكلاء في المدارس

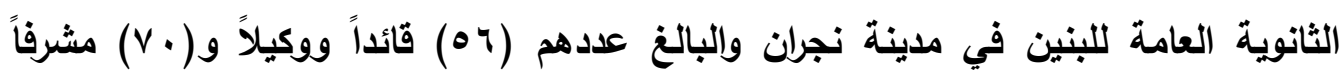

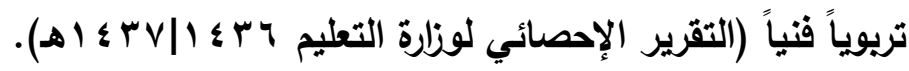

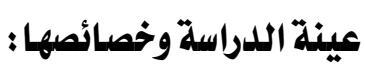

قام الباحث باختيار عينة عثوائية ممثلة المجتمع وتتكون من القيادات المدرسية

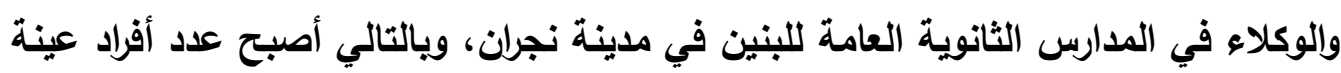
الداسة كالتالي: - الوكي

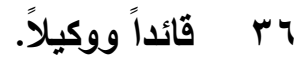
0 مشرفا تريوياً.

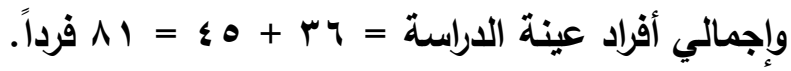
خصائص أفراد عينة الدراسلة:

جدول رقم (1) :توزيع عينة الدراسة وفقاً للمؤهل العلمي

\begin{tabular}{|c|c|c|}
\hline النسبة \% & التكرار & المؤهل \\
\hline$\wedge v, v$ & vi & بكالوريوس \\
\hline 11,1 & 9 & ماجستير \\
\hline $1, Y$ & 1 & دكتوراه \\
\hline
\end{tabular}


تحسين دور القيادات التبوية لتحقيق معايير جودة الأداء التدريسي...

$1 \ldots$,

$\wedge 1$

المجموع 
يظهر الجدول رقم (1) توزيع مجتمع الدراسة وفق المؤهل حيث يتبين أن معظم أفراد المجتمع

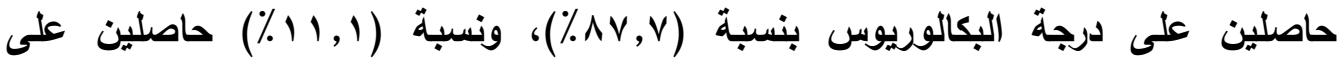
الماجستير، ونسبة (ץ, 1\%) فقط حاصلين على الدكتوراه.

\section{• عدد سنوات الخدمة}

جدول رقم (r): توزيع عينة الدراسة وفقاً لسنوات الخدمة

\begin{tabular}{|c|c|c|}
\hline النسبة \% & التكرار & سنوات الخدمة \\
\hline 11,1 & 9 & ه سنوات فأقلّ \\
\hline$r V, r$ & rr & من ه سنوات إلى · 1 سنوات \\
\hline$\because 1, \mathrm{~V}$ & ○. & من · ل 1 سنوات فأكثر \\
\hline $1 \cdots$, & $\wedge 1$ & 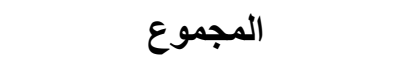 \\
\hline
\end{tabular}

يظهر الجدول رقم (ץ) توزيع مجتمع الاراسة وفق عدد سنوات الخدمة حيث يتبين أن

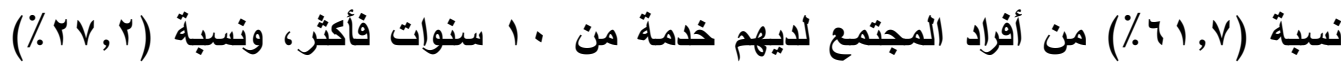

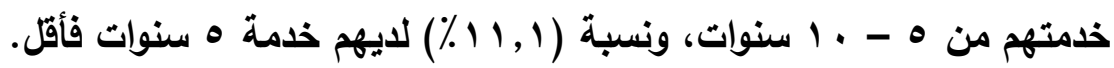

\section{الوظيفة}

جدول رقم (rّ): توزيع عينة الدراسة وفقاً للوظيفة

\begin{tabular}{|c|c|c|}
\hline النسبة \% & التكرار & الوظيفة \\
\hline $17,$. & ir & قائد مدرسة \\
\hline r^, \& & r & وكيل \\
\hline 00,7 & $\leqslant 0$ & مشرف تربوي \\
\hline $1 \ldots$, & $\wedge 1$ & المجموع \\
\hline
\end{tabular}

يظهر الجدول رقم (r) توزيع عينة الاراسة وفق للوظيفة حيث يتبين أن نسبة

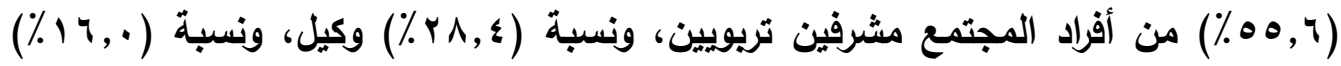

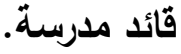


عدد اللدورات التدريبية في مجال إدارة العملية التربيوية

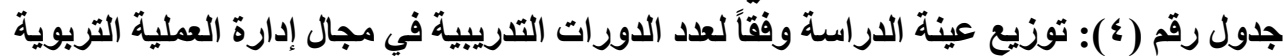

\begin{tabular}{|c|c|c|}
\hline النسبة \% & التكرار & عدد الدورات \\
\hline $7, Y$ & 0 & لم أحضر دورات \\
\hline$V_{7,0}$ & Tr & من 1 ـ r دورات \\
\hline IV,r & $1 \varepsilon$ & أكثر من (r) دورات \\
\hline $1 \cdots$, & $\Lambda_{1}$ & المجموع \\
\hline
\end{tabular}

يظهر الجدول رقم (ء) توزيع مجتمع الدراسة وفق عدد الدورات التدريبية في مجال

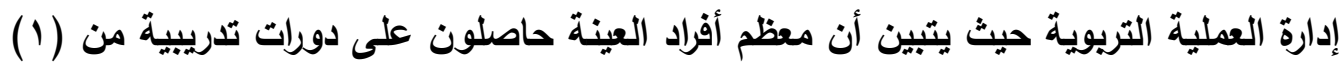

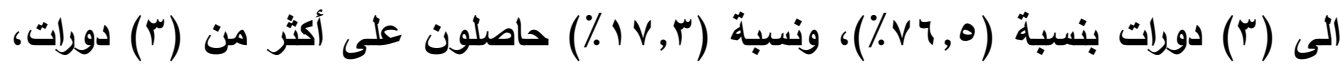
ونسبة (ץ, ؟ \%) لا يوجد لايهه دورات تدريبية في مجال إدارة العملية التريوية. أداةالدراسة:لتحقيق أهداف الدراسة قام الباحث بإعداد استبانة لجمع البيانات المتعلقة بموضوع البحث وذلك من خلال اتباع الخطوات التالية:

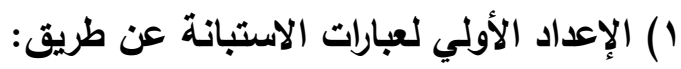

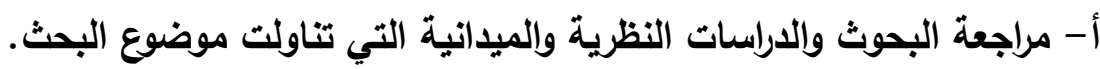
ب - خبرة الباحث في مجال العمل. r) من خلال الريط بين الدراسات النظرية والميدانية تم إعداد الاستبانة في صورتها الأولية مكونة من جزائن • الجزء الأول: يحتوي على بيانات شخصية تتضمن المؤهل التعليمي، وسنوات الخبرة، والوظيفة، وعدد الدورات التدريبية في مجال إدارة العملية التريوية. الجزء الثاني: يشتمل على محاور الدراسة، وهي ثلاثة محاور: - المحور الأول: ويهدف إلى تعرف مستوى ممارسات القيادات التريوية بالمدرسة الثانوية

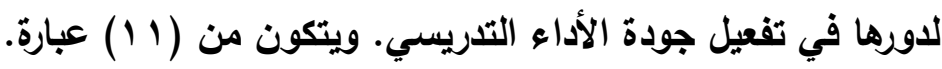
- المحور الثاني: ويهدف إلى تعرف صعويات دور القيادات المدرسية حيال تحقيق جودة الأداء التدريسي ويتكون من (9) عبارات. 
- المحور الثالث: ويهدف إلى تعرف سبل التظلب على صعويات دور القيادات المدرسية لتحقيق جودة الأداء التدريسي ويتكون من (• • ) عبارات.

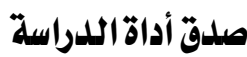

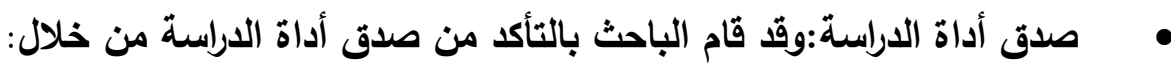

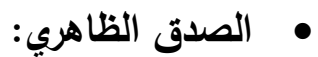

تم عرض الاستبانة في صورتها الأولية على مجموعة من المحكمين المختصين في المجال العلمي، وتم إباءاء الرأي من الدحكمين في مدى وضوح عبارات أداة الدراسة، ومدىى

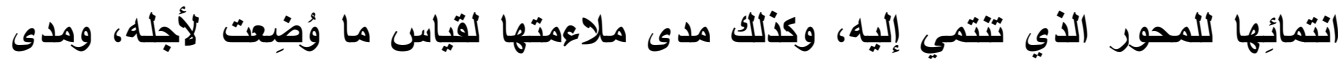

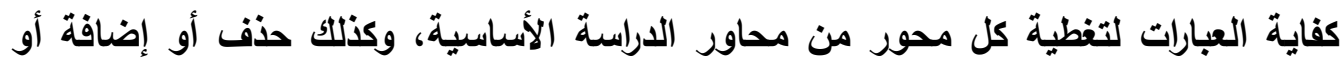

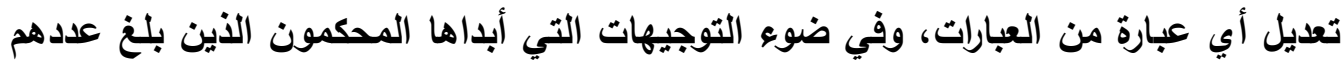
(11) محكماً، قام الباحث بإجراء التعديلات التي اتفق عليها معظم المحكمين على أداداة الدراسة، سواءً تعديل الصياغة في بعض العاراء العارات بعد تحديد مواضع الالتباس والضعف فيها

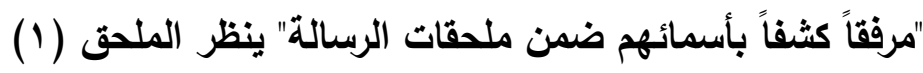

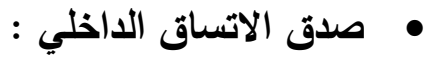

بعد التصميم النهائي لأداة الدراسة، ويعد التأكد من الصدق الظاهري لها باختيار مجموعة كعينة استطلاعية مكونة من (10) مفردة من مجتمع الاراسة، تم احتساب معاملات الارتباط بين كل عبارة والدرجة الكلية لجميع عبارات المحور الذي يتضمنها، كما هو موضح الده

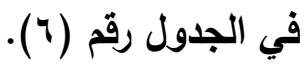


جدول رقم (7): معاملات ارتباط بيرسون بين العبارة والمجال والمحور الأي تتتمي إليه

\begin{tabular}{|c|c|c|c|c|c|}
\hline معامل الارتباط & الفقزة & معامل الارتباط & الفقزة & معامل الارتباط & الفقزة \\
\hline \multicolumn{2}{|c|}{ المحور الثالث } & \multicolumn{2}{|c|}{ المحور الثاني } & \multicolumn{2}{|c|}{ المحور الأول } \\
\hline$* *, 00$ & 1 & $* *, 77$ & 1 & $* *, \vee \vee 0$ & 1 \\
\hline$* *,, \vee 1$ & $r$ & $* *, 0$. & $r$ & $* *, 01$ & $r$ \\
\hline$* *, 7 r$ & $\mu$ & $* *,\{\}$ & $\mu$ & $* *, 07$ & $\mu$ \\
\hline$* *, V \varepsilon$ & $\varepsilon$ & $* *, 7$. & $\varepsilon$ & $* *, 7 V$ & $\varepsilon$ \\
\hline$* *, \vee \vee 7$ & 0 & $* *, 79$ & 0 & $* *, y r$ & 0 \\
\hline$* *, V \mu$ & 7 & $* *, 77$ & 7 & $* *, 7 \mu$ & 7 \\
\hline$* *, 77$ & $\bar{V}$ & $* *, 09$ & $\bar{V}$ & $* *, \leq \leq \varepsilon$ & $\mathrm{V}$ \\
\hline$* *, \vee \vee \wedge$ & $\Lambda$ & $* *, 7 \varepsilon$ & $\Lambda$ & $* *, Y Y$ & $\Lambda$ \\
\hline$* *,, \vee \wedge$ & 9 & $* *,, \Delta \Lambda$ & 9 & $* *, y Y$ & 9 \\
\hline$* *, 71$ & 1. & & & $* * ., 77$ & 1. \\
\hline & & & & $* *,, \vee 0$ & 11 \\
\hline
\end{tabular}

وق أظهر الجدول رقم (؟) الأي يوضح معاملات الارتباط بين درجة كل عبارة من عبارات الاستبانة، ودرجة جميع عبارات المحور الأي تنتمي إليه، مما يؤكد وجود علاقة ارتباط موجبة ومعنوية بين عبارات كل محور من محاور الدراسة والمحور الذي ينتمي إليه مما يعطي مصداقية مرتفعة لبناء أداة الاراسة عند (1 (.,·) كما أنه يلال على الاتساق الاخلي بين جميع عبارات محاور أداة الدراسة. ثبات أداة الدراسة: تم حساب معامل "ألفا كرو نباخ" للاستبانة ومحاور الدراسة؛ حيث أظهرت ثباتاً مرتفعاً كما يظهر في الجدول رقم (V): جدول رقم (V): معامل الثبات لمحاور الاراسة

\begin{tabular}{|c|c|c|}
\hline معامل الثبات & عدد الفقرات & المحور \\
\hline$\cdot, \wedge \varepsilon$ & 11 & المحور الأول \\
\hline$\cdot, V V$ & 9 & المحور الثاني \\
\hline$\cdot, \wedge r$ & 1. & المحور الثالث \\
\hline$\cdot, \wedge 9$ & $\mu$ & الاستبانة \\
\hline
\end{tabular}




\section{عرض نتائج البحث ومنـاقشتها}

أولاً: مستوى ممارسات القيادات التريوية بالمدرسة الثانوية لدورها في تفعيل جودة

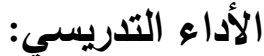

لتعرف واقع اتجاهات أفراد الدراسة نحو مستوى ممارسات القيادات التربوية بالمدرسة الثانوية لاورها في تفعيل جودة الأداء التدريسي تم حساب التكرارات والنسب المئوية والمتوسطات الحسابية والانحرافات المعيارية لإجابات أفراد الدراسة تجاه درجة ممارسة

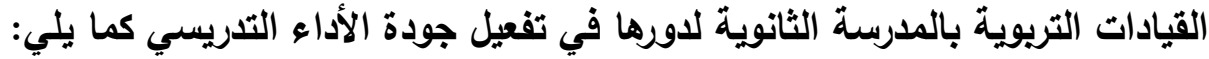

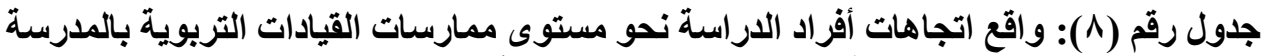
الثانوية لدورها في تفعيل جودة الأداء التدريسي التئي

\begin{tabular}{|c|c|c|c|c|c|c|c|c|}
\hline \multirow[b]{2}{*}{ الترتيب } & \multirow{2}{*}{ المعياري } & \multirow[b]{2}{*}{ المتوسط } & \multicolumn{3}{|c|}{ درجة الموافقة } & \multirow{2}{*}{\multicolumn{2}{|c|}{ العبارة }} & \multirow[b]{2}{*}{ r } \\
\hline & & & موأفير & محايد & موافث & & & \\
\hline \multirow{2}{*}{$r$} & \multirow{2}{*}{ •, \&. } & \multirow{2}{*}{$Y, \wedge \varepsilon$} & 1 & 11 & 79 & ت & \multirow{2}{*}{ تلى تحسير أنشطين مستوى مصاحبة تلطعل } & \multirow{2}{*}{1} \\
\hline & & & $1, Y$ & $1 \%, 7$ & $\Lambda \bullet, r$ & $\%$ & & \\
\hline \multirow{2}{*}{$\varepsilon$} & \multirow{2}{*}{$\cdot, \varepsilon r$} & \multirow{2}{*}{$Y, \wedge \varepsilon$} & $r$ & 9 & $V$. & ت & \multirow{2}{*}{ 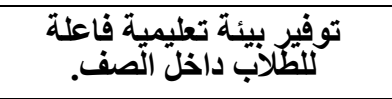 } & \multirow{2}{*}{$r$} \\
\hline & & & Y,O & 11,1 & $\Lambda \curlyvee, \varepsilon$ & $\%$ & & \\
\hline \multirow{2}{*}{1} & \multirow{2}{*}{ • מ } & \multirow{2}{*}{$r, \wedge q$} & 1 & $V$ & $V Y$ & ت & \multirow{2}{*}{ 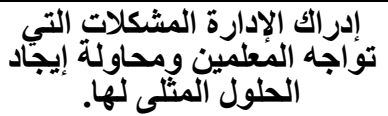 } & \multirow{2}{*}{$r$} \\
\hline & & & $1, r$ & $\Lambda, 7$ & $9 \cdot, 1$ & $\%$ & & \\
\hline \multirow{2}{*}{ V } & \multirow{2}{*}{$\cdot, \diamond \wedge$} & \multirow{2}{*}{$r, V V$} & 7 & V & 71 & ت & \multirow{2}{*}{ 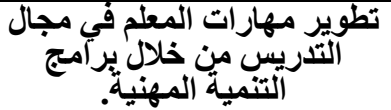 } & \multirow{2}{*}{$\varepsilon$} \\
\hline & & & $V, \varepsilon$ & $\Lambda, \nearrow$ & $\Lambda \varepsilon$ & $\%$ & & \\
\hline \multirow{2}{*}{7} & \multirow{2}{*}{$\bullet, \leqslant 0$} & \multirow{2}{*}{$Y, \wedge l$} & $r$ & 11 & 71 & ت & \multirow{2}{*}{ 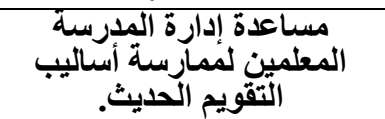 } & \multirow{2}{*}{0} \\
\hline & & & $Y, 0$ & $1 T, 7$ & $\Lambda \leq$ & $\%$ & & \\
\hline \multirow{2}{*}{9} & \multirow{2}{*}{$\cdot, O r$} & \multirow{2}{*}{$r, V r$} & $r$ & 17 & $7 r$ & ت & لمرسة & 4 \\
\hline & & & $r, V$ & 19,1 & $7 q, 0$ & $\%$ & & \\
\hline r & ד. & Y,$\wedge 0$ & - & Ir & 79 & ت & استخ & $\mathrm{V}$ \\
\hline & & & - & $1 \varepsilon, 1$ & $\Lambda \theta, r$ & $\%$ & تدرب & \\
\hline$\hat{A}$ & 01 & r yo & $r$ & $1 \varepsilon$ & 78 & ت & توفير & $\Lambda$ \\
\hline & 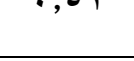 & 1,8 & $r, \mathrm{~V}$ & IV,r & $\sqrt{79}$ & $\%$ & & \\
\hline 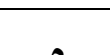 & & & $Y$ & 9 & $V$. & ت & تطيق القيم الاسلامية و الثقافة & \\
\hline 0 & $\bullet, \varepsilon P$ & $\uparrow, \wedge \varepsilon$ & $r, 0$ & 11,1 & $\wedge \neg, \varepsilon$ & $\%$ & تدريس. & 9 \\
\hline 11 & r & $r, \Delta r$ & 7 & YY & $\varepsilon 9$ & ت & أن يُعني بـ & 1. \\
\hline & & & $\mathrm{V}, \boldsymbol{\varepsilon}$ & rY, I & $7 \cdot, 0$ & $\%$ & & \\
\hline
\end{tabular}


تحسين دور القيادات التربوية لتحقيق معايير جودة الأداء التدريسي.

\begin{tabular}{|c|c|c|c|c|c|c|c|c|}
\hline \multirow[b]{2}{*}{ الترتيب } & \multirow{2}{*}{ الالمعياري اف } & \multirow{2}{*}{ المتوسط } & \multicolumn{3}{|c|}{ درجة الموافقة } & \multirow{2}{*}{\multicolumn{2}{|c|}{ العبارة }} & \multirow[b]{2}{*}{ م } \\
\hline & & & موافثيق & محايد & موافق & & & \\
\hline \multirow{2}{*}{1.} & \multirow{2}{*}{$\cdot, \Delta V$} & \multirow{2}{*}{$r, V r$} & 0 & Ir & $7 \varepsilon$ & ت & آن تُعنى الإدإِرة اله & \\
\hline & & & $7, Y$ & $1 \varepsilon, 1$ & $\vee q$ & $\%$ & ألبناءة في التدريس. & \\
\hline$\cdot, r$. & \multicolumn{2}{|c|}{$r, \vee \wedge$} & \multicolumn{6}{|c|}{ 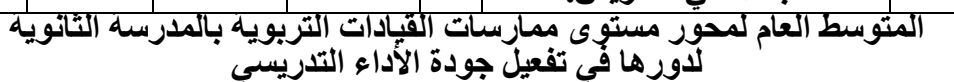 } \\
\hline
\end{tabular}

يتضح من الجدول رقم (^) أن محور مستوى ممارسات القيادات التريوية بالمدرسة الثانوية لدورها في تفعيل جودة الأداء التدريسي يتضمن (11) عبارة، حصلت جميع عباراته

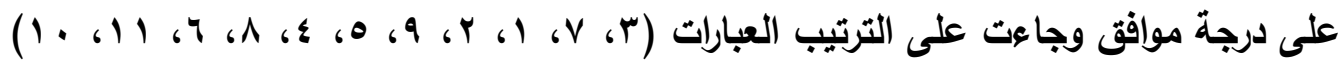

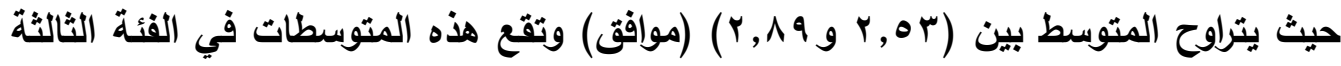
من فئات المقياس المتدرج الثلاثي التي تتراوح بين (ع ب, - r r) (موافق) ويلغ المتوسط الحسابي العام لجميع عبارات المحور (r,V^) أي إن أفراد الدراسة موافقون على محور

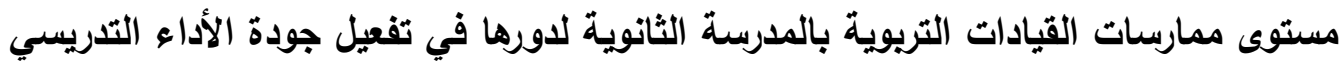

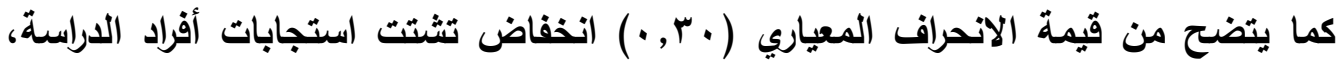
وتجانس استجابتهم حيال هذا المحور. حيث جاهت العبارة " إدراك الإدارة المشكلات التي تواجه المعلمين ومحاولة إيجاد الحلول المثلى لها " من أهم ممارسات القيادة التربوية بالمدرسة الثانوية لاورها في تفعيل جودة الأداء التدريسي بمتوسط 9,_, r, (موافق) ويفسر الباحث ذلك بأن القائد المدرسي عليه واجب ومسؤولية في إيجاد الحلول للمشكلات التي تواجه المعلمين، ويأتي هذا تمهيداً لتحقيق جودة الأداء التدريسي، وتتفق هذه النتيجة مع دراسة آل سحران (v . . rم)، وكذلك تتوافق هذه النتيجة مع المنطق التربوي السديد لاور القائد المدرسي فهو المعني بالدرجة الأول بإيجاد حلول للمشكلات القائمة في المدرسة. وجاءت العبارة " استخدام طرق وأساليب تدريس حديثة ومتنوعة " في المرتبة الثانية بمتوسط ه,^, ثم العبارة توفير أنشطة مصاحبة تعمل على تحسين مستوى الطلاب بمتوسط ع Y,_ " موافق " ويفسر الباحث ذلك بأن أفراد عينة الدراسة يرون أنه عند قيام المعلم باستخدام طرق وأساليب تدريس حديثة داخل حجرة الدراسة يساعد ذلك على تحقيق جودة

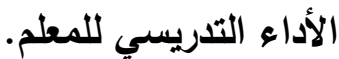

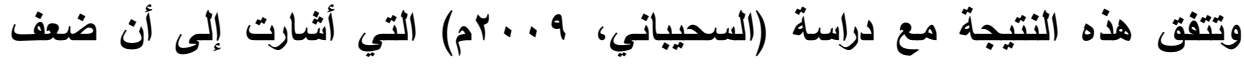


التفكير الإبداعي في تخطيط الدرس يؤدي إلى ضعف المعلم في تنمية التفكير الإبداعي في تنفيذ الارس.

ثم الممارسة الخاصة " بتوفير أنشطة مصاحبة تعمل على تحسين مستوى الطلاب " بمتوسط " ؟ ؟, ؟" ويفسر الباحث ذللك بأن القيادة التربوية ترى أن من المهم توفير أنشطة مصاحبة سواء صفية أو لا صفية تعمل على تحسين مستوى الطلاب مما يساعد على تحقيق جودة الأداء التاريسي.

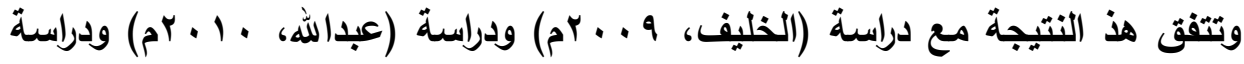

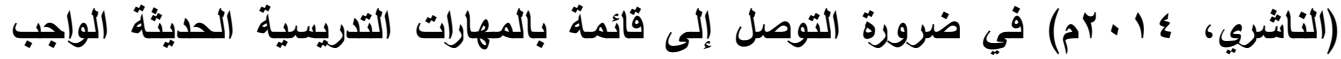
توفرها في المعلمين وتزويدهم بالاستراتيجيات التدريسية الحديثة التي تساعدهم على تنمية المجالات العقلية والوجداتية للطلاب.

بينما جاهت أقل ممارسات القيادات التريوية من وجهة نظر أفراد عينة الدراسة

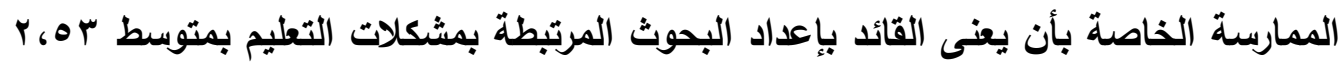

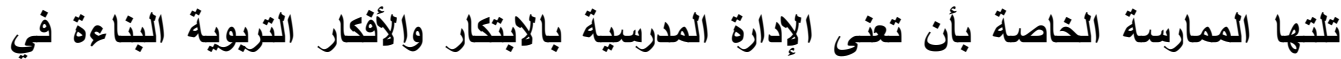

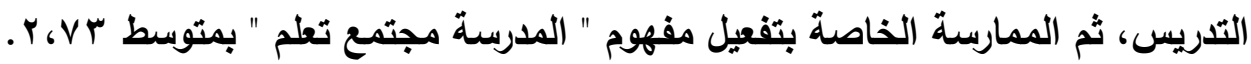
ويالتدقيق أكثر في أهم الممارسات التي يقوم بها القيادات التربوية بالمدرسة الثانوية نجد أنها تأخذ الثكل التقلياي في الإدارة التي تعنى بإدراك المشكلات والعمل على حلها، ومحاولة توفير بيئة تعليمية مناسبة من حيث طرق التدريس المتنوعة والفاعلة مع توفير بالئرسي أنشطة مصاحبة تعمل على تحسين مستوى الطلاب ولكن ينقصها بشكل كبير البحث عما هو جديد من خلال قيامهم بإعداد البحوث المرتبطة بالعملية التعليمية أو الاعتناء بابتكار حلول جديدة لمشكلات تعليمية قائمة، وكأن هذه المهام ليست من مهام القائد التريوي. من خلال السؤال المفتوح بعنوان ( ممارسات أخرى يرى أفراد الدراسة أهميتها) يتبين أن معظم أفراد الدراسة موافقون على عددٍ من الممارسات يرون أهميتها في دور القائد

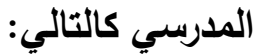

ممارسات تجاه المعلمين تمثلت في تحديد الاحتياجات التدريبية للمعلمين ومساعدة حديثي التخرج منهم لتطوير مستواهم من خلال عقد دورات تدريبية خاصة بهم، والاهتمام بتحفيز المعلمين مادياً ومعنوياً. 
كما أثاروا إلى ممارسات إدارية خاصة بهم مثل توفير الدورات التدريبية المناسبة للإدارة المدرسية وتكليف إداريين بتدريب عالٍ لمساعدة قائد المدرسة في الأعباء الموكلة

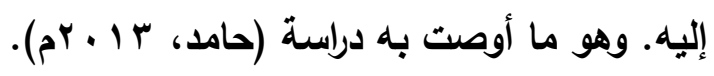

وممارسات خاصة بالمجتمع الخارجي للمدرسة مثل العمل على إشراك المجتمع في العملية التعليمية وإلتريوية من خلال الأنثطة المختلفة لربط المدرسة بالمجتمع وتفعيل دور الأسرة في مختلف مجالات التعليم وامتثال القيم التريوية النبيلة داخل المدرسة. من خلال الممارسات التي اقترحتها أفراد عينة الاراسة نجد أن معظمها منصب على توفير بيئة عمل داعمة للمعلمين وقد اتفقت هذه الممارسات مع دراسة (أبو حامد، ب ا • Yم) التي أوصت بتطوير برامج تأهيل المديرين ودوراتهم وأن تعمل القيادات المدرسية على توفير بيئة عمل داعمة للمعلمين.

\section{ثانياً : صعوبـات دور القيادات المدرسية حيال تحقيق جودة الأداء التدريسي}

للتعرف على واقع اتجاهات أفراد الدراسة نحو صعويات دور القيادات المدرسية حيال تحقيق جودة الأداء التدريسي تم حساب التكرارات والنسب المئوية والمتوسطات الحسابية والانحرافات المعيارية لإجابات أفراد الدراسة تجاه درجة صعويات دور القيادات المدرسية حيال تحقيق جودة الأداء التدريسي كما يلي: والئ جدول رقم (9): واقع اتجاهات أفراد الدراسة نحو لحم صعوبات دور القيادات المدرسية حيال تحقيق جودة الأداء

\begin{tabular}{|c|c|c|c|c|c|c|c|c|}
\hline \multicolumn{9}{|c|}{ التدريسي } \\
\hline \multirow[b]{2}{*}{ الترتيب } & \multirow{2}{*}{ 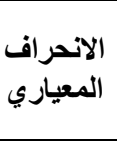 } & \multirow[b]{2}{*}{ المتوسط } & \multicolumn{3}{|c|}{ درجة الموافقة } & \multirow{2}{*}{\multicolumn{2}{|c|}{ العبارة }} & \\
\hline & & & موافير & محايد & موافق - مافق & & & \\
\hline \multirow{2}{*}{1} & \multirow[b]{2}{*}{ o } & \multirow{2}{*}{ ץ,૫. } & $\mathrm{v}$ & 11 & 04 & 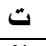 & \multirow{2}{*}{ ضعف ثقافة الجودة لاى بعض } & \\
\hline & & & $\Lambda, \uparrow$ & YY,Y & 79,1 & $\%$ & & \\
\hline \multirow{2}{*}{ r } & \multirow{2}{*}{$\cdot, v_{1}$} & \multirow{2}{*}{ 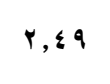 } & 1. & r) & o. & 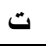 & \multirow{2}{*}{ تحسين جودة الأداء التئريسي. لبرامج } & \\
\hline & & & Tr,r & $r 0, q$ & $\pi, \mathrm{V}$ & $\%$ & & \\
\hline \multirow{2}{*}{$r$} & \multirow{2}{*}{$\cdot, 70$} & \multirow{2}{*}{$r, \varepsilon \varepsilon$} & $\mathrm{v}$ & $r$ & $\leq \mu$ & $ت$ & \multirow{2}{*}{ علدم كفاية برامج التنمية المهنية } & \\
\hline & & & $\Lambda, \uparrow$ & $r \wedge, r$ & $0 \%, 1$ & $\%$ & & \\
\hline \multirow{2}{*}{ A } & \multirow{2}{*}{$\cdot, \mathrm{V} 4$} & \multirow{2}{*}{$r, 10$} & 11 & $r \mu$ & r. & 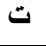 & \multirow{2}{*}{ الثقة بين المعلمين والقيادات } & \\
\hline & & & YY,Y & $\varepsilon \cdot, v$ & rv & $\%$ & & \\
\hline \multirow{2}{*}{$\mathrm{v}$} & \multirow{2}{*}{$\cdot, \wedge \varepsilon$} & \multirow{2}{*}{$r, r V$} & $r$. & 19 & $\varepsilon r$ & $ت$ & \multirow{2}{*}{ التربوية العليا والقيادات المدرسية. } & \\
\hline & & & $Y \leqslant, V$ & $r \mu, 0$ & 01,9 & $\%$ & & \\
\hline \multirow[t]{2}{*}{7} & \multirow{2}{*}{$\cdot, \mathrm{v}_{0}$} & \multirow{2}{*}{$r, r}$. & $1 \leq$ & rq & rᄉ & $ت$ & \multirow{2}{*}{ ضعف نشر ثقافة الجودة من قبل } & 7 \\
\hline & & & IV,r & $r 0, \Lambda$ & $\leq 4,9$ & $\%$ & & \\
\hline • & $\cdot, \mathrm{Vr}$ & r,rr & ir & $r_{1}$ & rs & 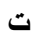 & انشغال الإدارة المدرسية بتطبيق & $\mathrm{v}$ \\
\hline
\end{tabular}




\begin{tabular}{|c|c|c|c|c|c|c|c|c|}
\hline & & & $1 \leq, 1$ & $r \wedge, r$ & $\leq 7,9$ & $\%$ & معايير جودة الأداء التدريسي & \\
\hline \multirow{2}{*}{$\varepsilon$} & \multirow{2}{*}{$\cdot, v$} & \multirow{2}{*}{$r, \leqslant \varepsilon$} & $1 r$ & 19 & $\leqslant 9$ & ت & \multirow{2}{*}{ ضعف مستوى التجهيزات والمعامل } & \multirow{2}{*}{$\wedge$} \\
\hline & & & 17 & rr,o & $7 \cdot, 0$ & $\%$ & & \\
\hline \multirow{2}{*}{9} & \multirow{2}{*}{$\cdot, \wedge \wedge$} & \multirow{2}{*}{$r, \cdot \bullet$} & rq & 19 & $r T$ & ت & \multirow{2}{*}{ عدم وضوح لايحة الثواب والعقاب. } & \multirow{2}{*}{9} \\
\hline & & & $r \theta, \Lambda$ & $r r, 0$ & $\varepsilon \cdot, V$ & $\%$ & & \\
\hline \multicolumn{2}{|c|}{$\cdot, \leqslant \varepsilon$} & $r, r \leqslant$ & \multicolumn{6}{|c|}{ المتوسط العام لمحور صعوبات دور القيادات المدرسية حيال تحقيق جودة الأداء } \\
\hline
\end{tabular}

يتضح من الجدول رقم (9) أن محور صعويات دور القيادات المدرسية حيال تحقيق جودة الأداء التدريسي يتضمن (9) عبارات، جاعت أريع عبارات منها بلرجة موافقة، وهي

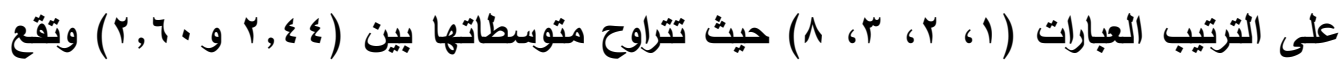
هذه المتوسطات في الفئة الثالثة من فئات المقياس المتدرج الثلاثي التي تثراوح بين

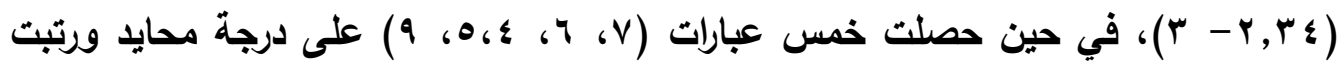

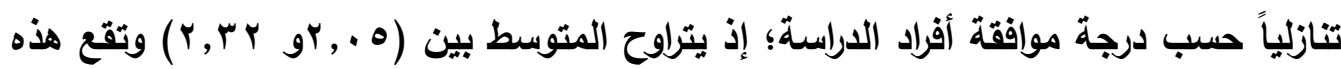

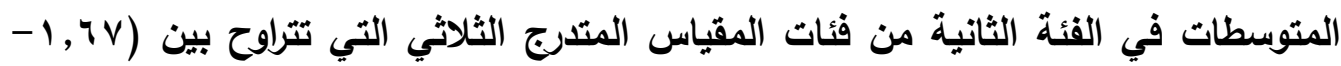

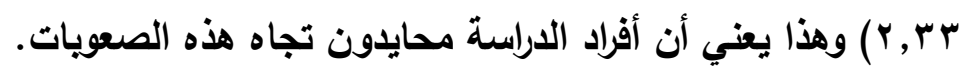
ويلغ المتوسط الحسابي العام لجميع عبارات محور صعويات دور القيادات المدرسية

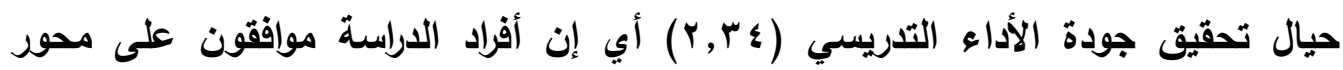

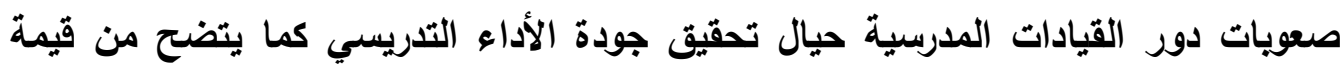
الانحراف المعياري (؟ ؟, •) انخفاض تثتت استجابات أفراد الدراسة، وتجانس استجابتهم حيال هذا المحور. يتبين من النتائج أن أبرز هذه الصعويات من وجهه نظرهم هي (ضعف ثقافة الجودة

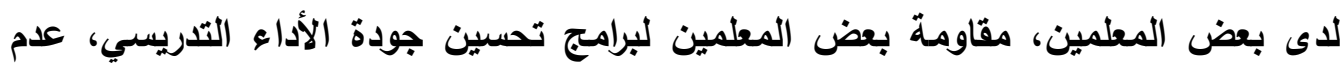

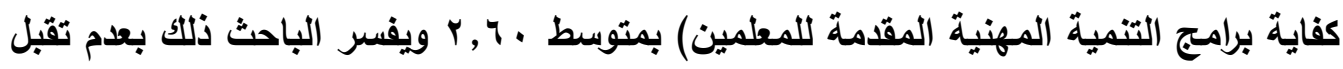

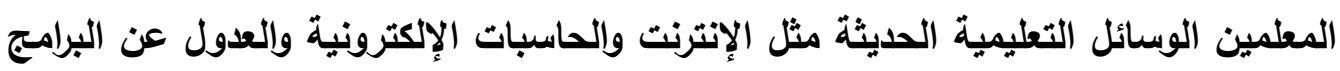

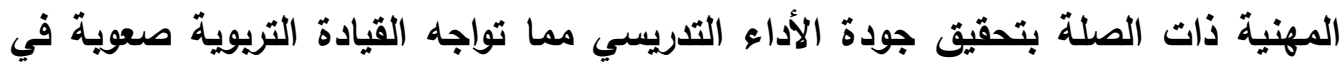
تحقيق الأداء التدريسي أو قد يرجع إلى مقاومة المعلمين للتغيير.

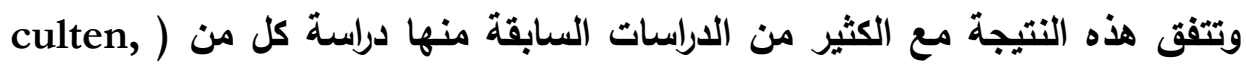

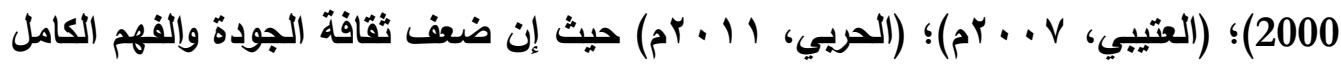
للجودة عند بعض المعلمين يعد من الصعويات في تحقيق جودة الأداء التدريسي والعملية 
كما وضح أفراد عينة الدراسة بأن من أهم الصعويات حيال تحقيق جودة الأداء

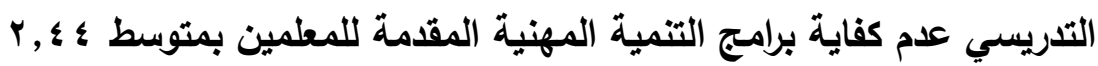
ولذلك يلاحظ الباحث من خلال جدول (9) أن أفراد عينة الدراسة أشاروا إلى أن أهم الصعويات التي تواجه تحقيق جودة الأداء التدريسي هو المعلم ويفسر الباحث ذلك بأن المعلم هو الموكل الأول لتحقيق تلك الجودة المنشودة من خلال المهام التعليمية المنوط بها داخل الغرفة الصفية وخارجها من إعداد وتنفيذ وتخطيط لتحقيق أهداف معينة. كما يتضح من إجابات مديري ووكلاء المدارس الثانوية والمشرفين التريويين في مدينة نجران على السؤال المفتوح اتفاقهم أن هناك صعويات أخرى تعوق دور القيادات المدرسية حيال تحقيق جودة الأداء التدريسي وهي كالتالي: صعويات خاصة بالقائد نفسه مثل عدم توفر صلاحيات لقائد المدرسة لتحفيز المعلم المميز، وعلم تحفيز المعلمين وإنصافهم في أعمالهم، وضعف معايير اختيار قائد المدرسة، وصعويات إدارية متمثلة في نقص الكوادر الإدارية بالمدرسة وعدم تفعيل دور المتابعة لمتطلبات المدرسة، وعدم استجابة إدارة التعليم لطلبات المدارس ومتطلباتها وعدم توفز الإمكانات المادية ويعض هذه الصعويات أثشارت إليها بالفعل دراسة (detret\&others, 2001). صعويات خاصة بالمعلمين متمثلة في ضعف دافعية بعض المعلمين لمهنة التعليم، وقلة عدد المعلمين المتخصصين بالمدرسة، وعزوف بعض المعلمين عن التدريب والتطوير وهو ما أشارت إليه دراسة (العتيبي، V V. . rم). وصعويات مع المجتمع الخارجي متمثلة في ضعف علاقة الأسرة بالمدرسة وصعويات خاصة بالطلاب متمثلة في كثافة عدد الطلاب في الصفوف. ثالثاً : سبل التفلب على صعوبات دور القيادات الملدرسية لتحقيق جودة الأداء التدريسي للتعرف على واقع اتجاهات أفراد الدراسة نحو سبل التظلب على صعويات دور القيادات المدرسية لتحقيق جودة الأداء التريسي تم حساب التكرارات والنسب المئوية والمتوسطات الحسابية والانحرافات المعيارية لإجابات أفراد الاراسة تجاه سبل التظلب على صعويات دور القيادات المدرسية لتحقيق جودة الأداء التدريسي كما يلي: 
جدول رقم ( • 1): واقع اتجاهات أفراد الدراسة نحو سبل التظلب على صعوبات دور القيادات المدرسية لتحقيق

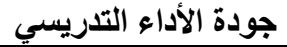

\begin{tabular}{|c|c|c|c|c|c|c|c|c|}
\hline \multirow[b]{2}{*}{ الترتيب } & \multirow{2}{*}{ الانحراف } & \multirow[b]{2}{*}{ المتوسط } & \multicolumn{3}{|c|}{ درجة الموافقة } & \multirow{2}{*}{\multicolumn{2}{|c|}{ 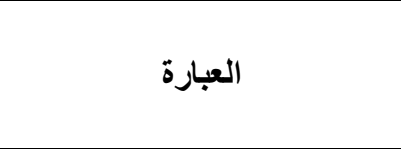 }} & \multirow[b]{2}{*}{ b } \\
\hline & & & موافيز & 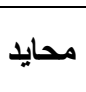 & 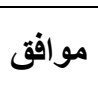 & & & \\
\hline \multirow{2}{*}{$r$} & \multirow{2}{*}{$\cdot, 01$} & \multirow{2}{*}{$\uparrow, \wedge$. } & $\varepsilon$ & $\wedge$ & 79 & $ت$ & \multirow{2}{*}{ تحديد أهداف المعلمين فئة } & \multirow{2}{*}{1} \\
\hline & & & $\varepsilon, 9$ & 9,9 & $\Lambda \bullet, r$ & $\%$ & & \\
\hline \multirow{2}{*}{0} & \multirow{2}{*}{$\cdot, 0 \leqslant$} & \multirow{2}{*}{$Y, Y \bullet$} & $\varepsilon$ & Ir & 70 & ت & \multirow{2}{*}{ المعلمين لتطوير الإدارة احتياجاتية } & \multirow{2}{*}{ r } \\
\hline & & & $\varepsilon, 9$ & $1 \varepsilon, \wedge$ & $\Lambda \cdot, r$ & $\%$ & & \\
\hline \multirow{2}{*}{7} & \multirow{2}{*}{$\cdot, 0 \leqslant$} & \multirow{2}{*}{$Y, V \varepsilon$} & $\varepsilon$ & 14 & $7 \varepsilon$ & $ت$ & \multirow{2}{*}{ تحسين طرق قياس الأداء } & \multirow{2}{*}{$r$} \\
\hline & & & $\varepsilon, 9$ & 17 & $\vee q$ & $\%$ & & \\
\hline \multirow{2}{*}{9} & \multirow{2}{*}{$\cdot, 09$} & \multirow{2}{*}{ Y, \V } & $\bullet$ & iv & 09 & $ت$ & \multirow{2}{*}{ توالميمن الحوافز للمعلمين. المادية. } & \multirow{2}{*}{$\varepsilon$} \\
\hline & & & $7, Y$ & Y & $\vee Y, \Lambda$ & $\%$ & & \\
\hline \multirow[b]{2}{*}{ r } & \multirow{2}{*}{$\cdot, \varepsilon \wedge$} & \multirow{2}{*}{$r, \wedge !$} & $r$ & 9 & 79 & $ت$ & \multirow{2}{*}{ 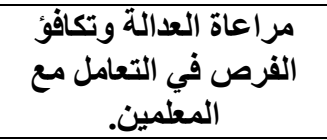 } & \multirow[b]{2}{*}{ • } \\
\hline & & & $r, v$ & 11,1 & $\Lambda \bullet, r$ & $\%$ & & \\
\hline \multirow{2}{*}{1} & \multirow{2}{*}{$\cdot, \leqslant 0$} & Y 11 & $r$ & 11 & 71 & $ت$ & إتاحة الفرص للمعلمين & 7 \\
\hline & & 1 & $r, 0$ & $1 \pi, 7$ & $\Lambda \varepsilon$ & $\%$ & لتطوير العمليا & \\
\hline & & & $\varepsilon$ & $r \cdot$ & $\Delta V$ & $ت$ & تحسين المناخ التنظيمي & \\
\hline 1. & , & 1,10 & $\varepsilon, 9$ & $r \leqslant, V$ & $V \cdot, \varepsilon$ & $\%$ & سية. & r \\
\hline & & & $\varepsilon$ & $1 \varepsilon$ & $\pi$ & $ت$ & إعداد برامج تدريبية من & \\
\hline v & $\cdot, 00$ & $r, v r$ & $\varepsilon, 9$ & IV,r & $\vee V, \Lambda$ & $\%$ & المدرسية لتحقيق دوريق معايير الجودة & $\wedge$ \\
\hline 4 & 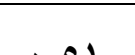 & ryo & $r$ & $1 \varepsilon$ & $7 \varepsilon$ & ت & نشر ثقافة الجودة في & 9 \\
\hline 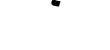 & 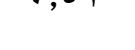 & $1, r e$ & $r, V$ & IV,r & $\vee 9$ & $\%$ & المجتمع المدرسي. & \\
\hline & & & $\bullet$ & 17 & 7. & $ت$ & دعم الأبحاث العلمية ذات & 1 \\
\hline$\wedge$ & 0,04 & $T, 7 \wedge$ & $\checkmark, r$ & 19,1 & $v \varepsilon, 1$ & $\%$ & التعلهفه بنطية. العمليه. & - \\
\hline & & $Y, V \varepsilon$ & & & لدريس & & 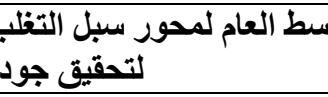 & \\
\hline
\end{tabular}

يتضح من الجدول رقم ( (1) أن سبل التظلب على صعوبات دور القيادات المدرسية لتحقيق جودة الأداء التدريسي يتضمن (. (1) عبارات، حصلث جميع عباراته على درجة

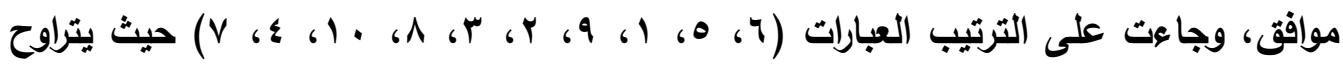

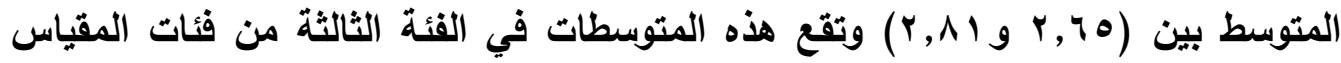




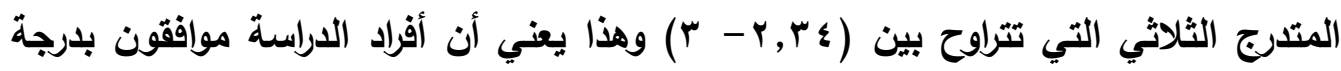
متقارية على سبل التظلب على صعويات دور القيادات المدرسية لتحقيق جودة الأداء

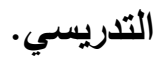

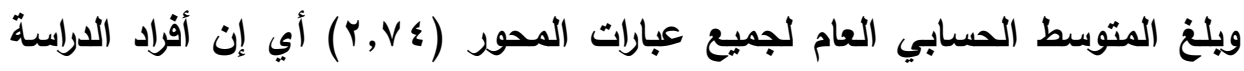
موافقون على محور سبل التظلب على صعويات دور القيادات الددرسية لتحقيق جودة الأداء التدريسي.

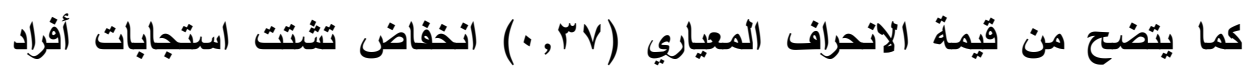
الاراسة، وتجانس استجابتهم حيال هذا المحور. - من خلال الجدول السابق نلاحظ أن العبارات التي حصلت على أعلى

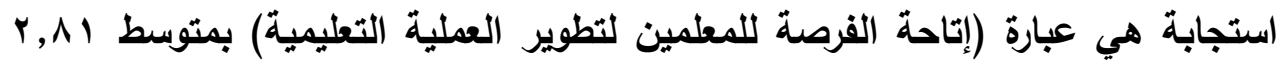

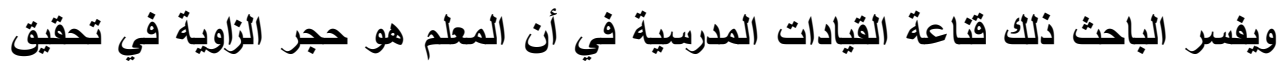
جودة الأداء المدرسي، ولذلك يجب إتاحة الفرصة للمعلمين للمشاركة في اتخاذ القرارات

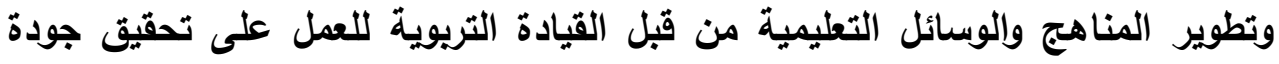

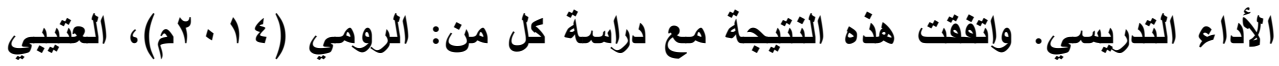
التي أوصت الجهات المختصة المسؤولة عن تطوير المعلم بحضور معلم الثانوية برنامجاً تدريباً واحداً كد أدنى، وكذلك تزويد المعلمين باستراتيجيات حديثة الثنات تساعدهم على تنمية المجالات العقلية والوجدانية للمعلمين.

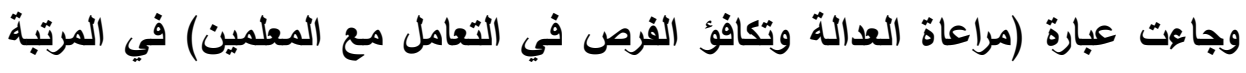

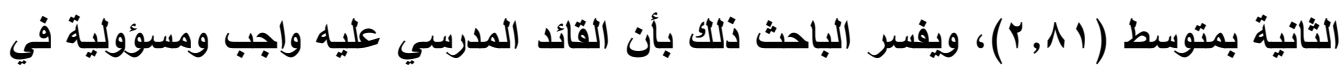

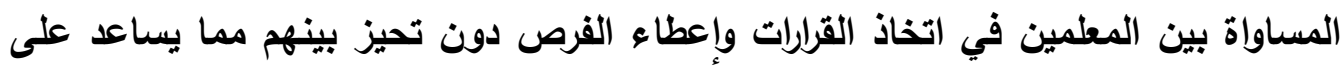
تحقيق جودة الأداء التدريسي؛ لأن شعور المعلم بالعدالة سوف ينعكس إيجاباً على أدائه

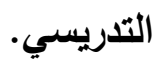

ثم جاءت العبارة (مشاركة المعلمين في تحديد أهداف المدرسة وروئيتها) في المرتبة الثالثة بمتوسط . r،A بحيث تتيح القيادة التريوية الفرصة للمعلمين في اتخاذ القرارات المدرسية ورسم سياستها وتحديد أهدافها. واتفقت هذه النتيجة مع دراسة (بوركو وآخرون،

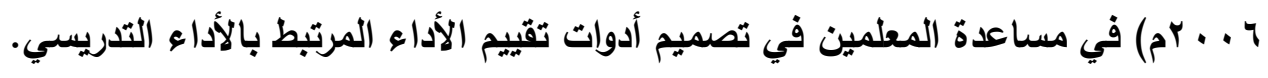


ويلاحظ الباحث من ذلك أن أفراد عينة الدراسة يرون أنه أهم سبل التظلب على صعويات دور القيادات المدرسية لتحقيق جودة الأداء التدريسي منصبة في المقام الأول على التى

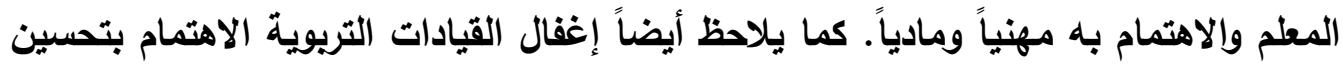

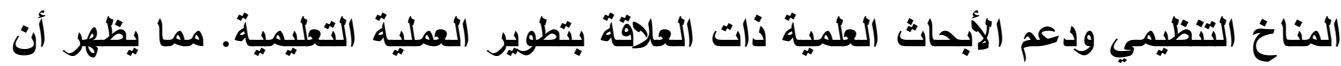
بعض القيادات التريوية يحمل الفكر التقليدي في الإدارة. يتبين من السؤال المفتوح أن أفراد عينة الدراسة موافقون على سبل أخرى يرون إضافتها لتحسين دور القيادات المدرسية في جودة الأداء التدريسي وهي كالتالي: التنمية المهنية للقائد المدرسي من خلال منح قائد المدرسة كامل الصلاحيات بشكل جاد وصادق. وتحفيز قادة الدارس وتلبية متطلباتهم. وإضافة معيار الداسات العليا في اختيار قائد المدرسة، وإداق قادة الددارس في دورات تدريبية نوعية، وإعطاء مقاعد أكثر للقيادات للحصول على الدورات القيادية المدرسية. كما أثناروا إلى إمكانية تحقيق جودة الأداء التدريسي من خلال تحفيز بعض الدئ المطلمين للقيام بأدوار إدارية مناسبة لقداتهم وتفعيل برنامج الابتعاث للمعلمين. ووضع خطط لتحقيق أهداف العملية التعليمية. وتفعيل نتائج البحوث والدراسات التريوية الخاصة بتطوير العملية التريوية.

ويلاحظ الباحث من اقتراحات أفراد عينة الدراسة أن معظمها طلبات تخص القائد الدرسي في المقام الأول مثل توسيع صلاحياته والاهتمام بتدريبه وطرق اختياره بالإضافة إلى المخصصات المالية الخاصة بإدارة المدرسة. رابعاً: الفروق ذات الدلالة الإحصائية بين متوسطات إجابات أفراد عينة الدراسة وفق المتفيرات

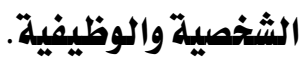
للتعرف على الفروق ذات الالالة إحصائية في استجابات أفراد العينة التي تعزى للمتغيرات الشخصية والوظيفية تم استخدام اختبار (ت) (T-test) لبيان الفروق بين استجابات أفراد العينة لمتغير المؤهل؛ لأن المتغير مكون من فئتين فقط، كما استخدم الباحث

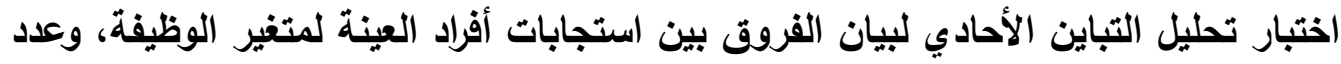

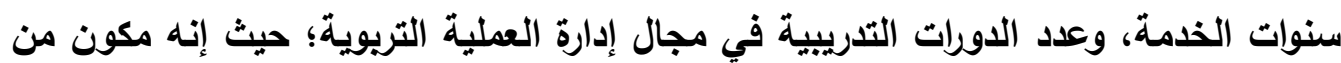

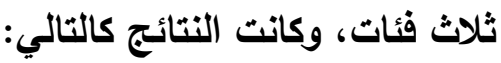


• المؤهل

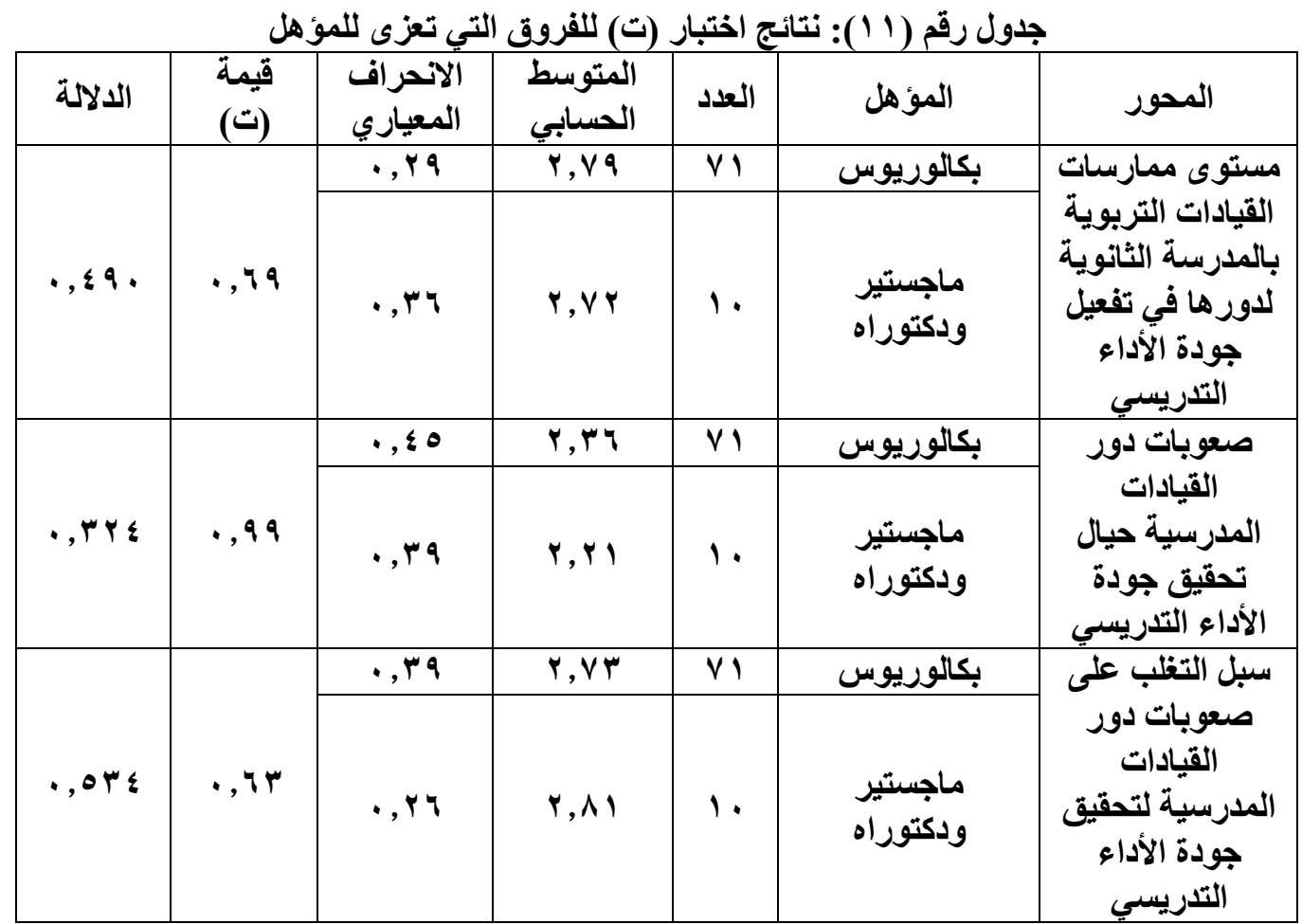

يظهر الجدول رقم (11) عدم وجود فروق ذات دلالة إحصائية في جميع محاور الدراسة تعزى للمؤهل، أي إن أفراد الدراسة باختلاف مؤهلاتهم متفقون في الرأي تجاه محاور الدراسة ويفسر الباحث ذلك بأن مؤهلاتهم ريما كاتت غير متخصصة في مجال القيادة التريوية سواء أكاتت بكالوريوس أو ماجستير أو دكتوراه أو كيفية تفعيل جودة الأداء

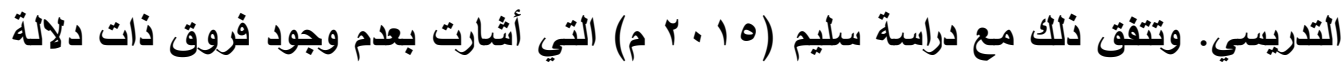
إحصائية بين المتوسطات الحسابية لارجة تطبيق المعلمين لمعايير الجودة الثاملة في التعليم تعزى إلى متغير المؤهل الاراسي 
عدد سنوات الخدمة

جدول رقم (r ( )): تحليل التباين الأحادي للفروق التي تعزى لعدد سنوات الخبرة

\begin{tabular}{|c|c|c|c|c|c|c|}
\hline الدلالة & قة فيمة & المربعات & الحرية & المربعوات & مصدار & المحور \\
\hline \multirow{2}{*}{., $.0 \mathrm{~V}$} & \multirow{2}{*}{$Y, q \vee V$} & $\cdot, r \circ 4$ & $r$ &., $01 Y$ & المجموعات & \multirow{2}{*}{ لالتربوية بالمدرسية مارسات الثياداتية } \\
\hline & & $\cdot, \wedge \neg$ & $\vee \wedge$ & $7, v \cdot 9$ & المجموعات & \\
\hline \multirow{2}{*}{$\cdot, \vee 7$} & \multirow{2}{*}{$\cdot, Y \vee T$} &,, 00 & $r$ & $\cdot, 111$ & المجموعات & \multirow{2}{*}{ 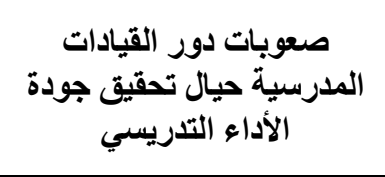 } \\
\hline & & $\cdot, r$ & $\vee \wedge$ & $10,7 \mathrm{VV}$ & المجموعات & \\
\hline \multirow{2}{*}{$\cdot, 19 \varepsilon$} & \multirow{2}{*}{$1,7 \vee V$} & - $r$ rq & $r$ & $\cdot, \leqslant 0 \wedge$ & المجموعات & \multirow{2}{*}{ سبل التظب على المدى صعوبة التحقيث دور } \\
\hline & & $\cdot, I T V$ & $\vee \wedge$ & $1 ., 7 \circ \mathrm{V}$ & المجموعات & \\
\hline
\end{tabular}

يظهر الجدول رقم (Y I) عدم وجود فروق ذات دلالة إحصائية في جميع محاور الدراسة تعزى لعدد سنوات الخبرة. أي إن أفراد الدراسة باختلاف خبراتهم متفقون في الرأي تجاه محاور الاراسة ويفسر الباحث ذلك بأن مفاهيم جودة الأداء التدريسي حديثة نسبياً في مدارسنا وممارسات تحقيقها على أرض الواقع جديدة على أغلب العاملين في العملية التعليمية بحيث لا تختلف ممن لايهم خبرة كبيرة أو حديثي العهر بالعمل الميداني في العملية

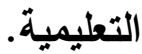

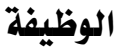

جدول رقم (r I ) ) تحليل التباين الأحادي للفروق التي تعزى للوظيفة

\begin{tabular}{|c|c|c|c|c|c|c|}
\hline الدلالة & قَّة & المربعات & الحرجة & المربعوع & مصدر التباين & المحور \\
\hline \multirow[b]{2}{*}{$\cdot, v \cdot r$} & \multirow[b]{2}{*}{ } & •, Mr & $r$ & $\cdot,+70$ & المجموعات & \multirow{2}{*}{ 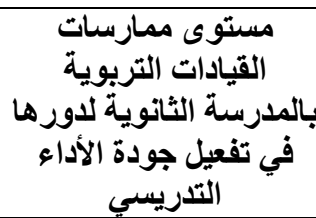 } \\
\hline & &., .94 & $\vee \wedge$ & $V, 107$ & المجموعات & \\
\hline \multirow{2}{*}{., .99} & \multirow{2}{*}{$r, r \wedge r$} & • , $\{0 \mu$ & r & $\cdot, 9 \cdot V$ & المجموعات & \multirow{2}{*}{ صودوبات دورية الأدياّ تحقيقات التدريسيق } \\
\hline & &., 19 & $\vee \wedge$ & $1 \leq, \wedge \leq 1$ & المجموعات & \\
\hline$\cdot, \leqslant 91$ & $\cdot, \nabla \wedge r$ &., 1.9 & r & $\cdot, Y 19$ & المجموعات & صعوبات دور التظبل على \\
\hline
\end{tabular}




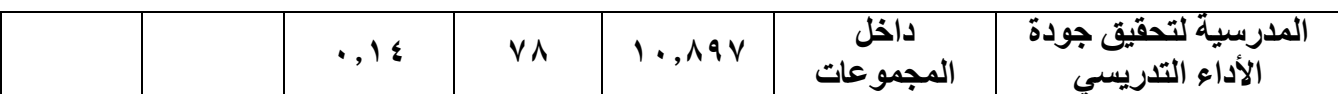

يظهر الجدول رقم (r) (I عدم وجود فروق ذات دلالة إحصائية في جميع محاور

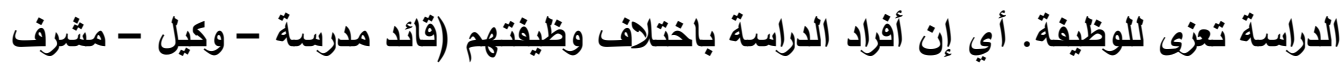
تريوي) متفقون في الرأي تجاه محاور الدراسة ويفسر الباحث ذلك بأن كل الوظائف التعليمية يتم اختيارها وفق آلية واحدة ويتلقون نفس الدورات التدريبية التي تهدف تنميتهم مهنياً ويالتالي فإن أغلبهم يحمل نفس التصور لكيفية الإدارة المدرسية وتحقيق جودة الأداء التدريسي.

\section{عدد اللدورات التدريبية في مجال إدارة العملية التزبوية}

جدول رقم (؛ ()): تحليل التباين الأحادي للفروق التي تعزى لعدال الادورات التدريبية

\begin{tabular}{|c|c|c|c|c|c|c|}
\hline الدلالة & قيمة (ف) & المربعات & الحرية & المربعوع & التباين & المحور \\
\hline \multirow{2}{*}{$\cdot, 1 \vee 9$} & \multirow{2}{*}{1,87} &., 104 & r & $\cdot, r \mid r$ & المجموعات & \multirow{2}{*}{ 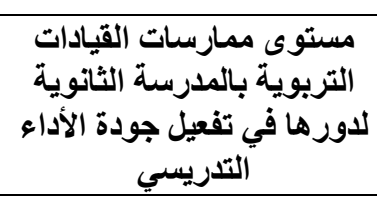 } \\
\hline & & $\cdot, \cdot \wedge q$ & $\vee \wedge$ & $7,9.9$ & المجموعات & \\
\hline \multirow{2}{*}{ • } & \multirow{2}{*}{$1, \ldots \varepsilon$} & $\cdot, 191$ & r & • & المجموعات & \multirow{2}{*}{ المدرسية حيال دور الحقيق جودةد } \\
\hline & &., $19 V$ & $\vee \wedge$ & $10, r \circ r$ & المجموعات & \\
\hline \multirow{2}{*}{ ש } & \multirow{2}{*}{ } & $\cdot, 1 \wedge V$ & $r$ & $\cdot, r v r$ & المجموعات & \multirow{2}{*}{ سبل التظلب على صعوبات المدرة دور الأداء التريسيق } \\
\hline & & $\cdot, \mid \Gamma \wedge$ & $\vee \wedge$ & $1 \cdot, v \leqslant r$ & المجموعات & \\
\hline
\end{tabular}

يظهر الجدول رقم (ع 1) عدم وجود فروق ذات دلالة إحصائية في جميع محاور

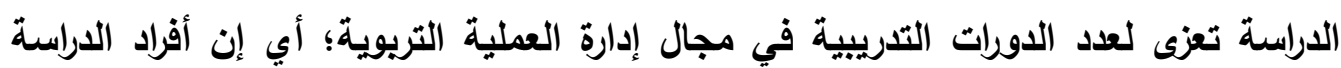
باختلاف عدد الدورات أو عدم وجود دورات متفقون في الرأي تجاه محاور الدراسة ويفسر

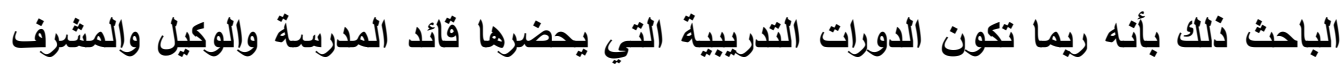

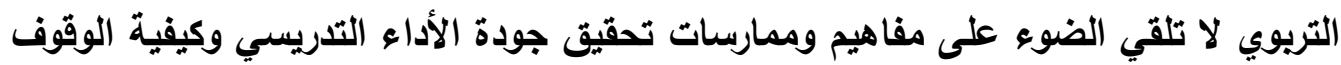
على نقاط قوة وضعف وتحديات وفرص تحقيق جودة الأداء التدريسي بمدارسنا. وهذا يتفق التقدي

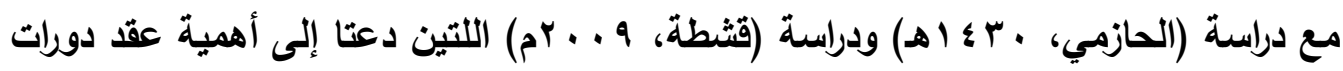
تدريبية تعمل على تحقيق جودة الأداء التدريسي. 


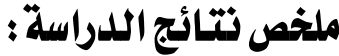

• أظهرت النتائج أن أفراد الاراسة بصفة عامة موافقون على مستوى ممارسات القيادات التريوية بالمدرسة الثانوية لدورها في تفعيل جودة الأداء التدريسي، وكانت استجابتهن متجانسة حيال هذا المحور، وحصلت جميع عباراته على درجة موافق، وهذه النتيجة

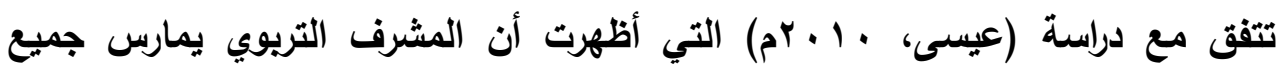

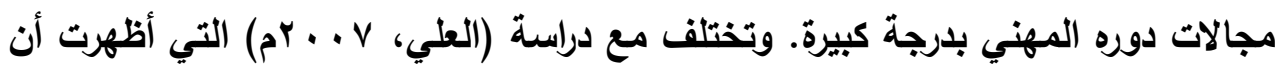

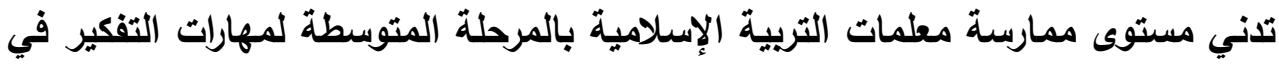

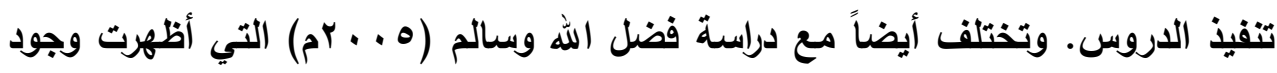
قصور في مستوى أداء معلمي اللغة العربية في تدريس القواعد النحوية بالمرحلة المتوسطة في ضوء معايير الجودة الثناملة. دراسة، وتختلف أيضاً مع دراسة (المزمومي،

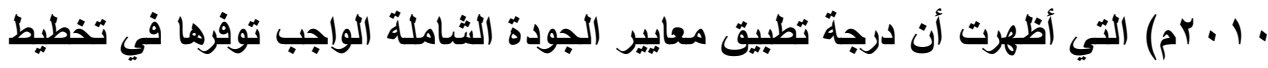

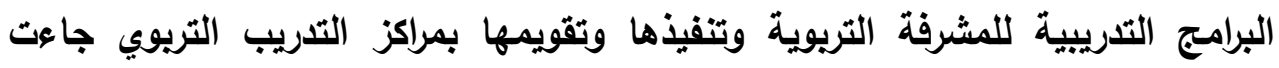
بدرجة متوسطة. وتختلف أيضاً مع دراسة (Detret \& Others 2001) التي أظهرت أن مديري المدارس يطبقون أسلوب إدارة الجودة الثاملة بدرجة متوسطة.

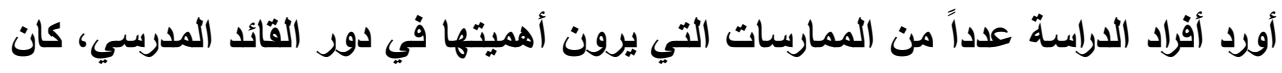
أهمها: توفير الدورات التدريبة المناسبة للإدارة الددرسية، وتحديد الاحتياجات التدريبية التدانية

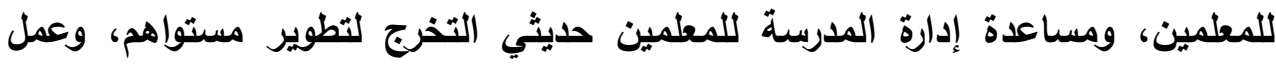
دورات تدريبة خاصة للددرس حديث التخرج، وتفعيل دور الأسرة في مختلف مجالات

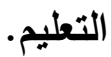

وأظهرت النتائج أن أفراد الدراسة موافقون على صعويات دور القيادات المدرسية حيال تحقيق جودة الأداء التدريسي، وكانت استجابتهن متجانسة حيال هذا المحور. • أورد أفراد الدراسة عدداً من الصعويات التي يرون أنها تعوق دور القائد المدرسي حيال

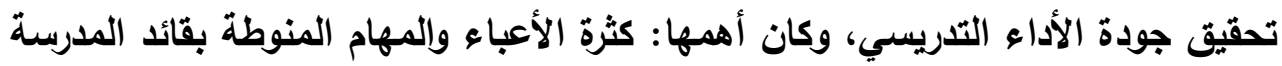

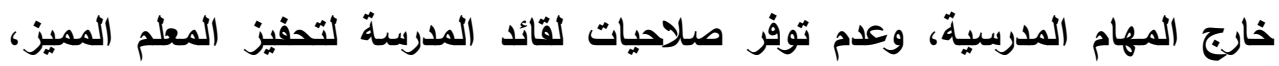


وضعف معايير اختيار قائد المدرسة، وضعف دافعية بعض المعلمين لمهنة التعليم، وعزوف بعض المعلمين عن التدريب والتطويز، وعدم توفر الإمكانات المادية، وضعف بهف علاقة الأسرة بالمدرسة، وكثافة عدد الطلاب في الصفوف. أظهرت النتائج أن أفراد الدراسة موافقون على سبل التظلب على صعويات دور القيادات المدرسية لتحقيق جودة الأداء التدريسي، وكانت استجابتهم متجانسة حيال هذا المحور، وحصلت جميع عباراته على درجة موافق. اقترح أفراد الدراسة عدداً من السبل التي يرون إضافتها لتحسين دور القيادات المدرسية في جودة الأداء التدريسي، وكان أهمها: منح قائد المدرسة كامل الصلاحيات بشكل جاد وصادق، وتحفيز قادة المدارس وتلبية متطلباتهم، وإضافة معيار الدراسات العليا في اختيار قائد المدرسة، وإلحاق قادة المدارس في دورات تدريبية نوعية، وإعطاء مقاعد أكثر للقيادات للحصول على الدورات القيادية المدرسية، وتحفيز بعض المعلمين للقيام بأدوار إدارية مناسبة لقدراتهم، وتفعيل برنامج الابتعاث للمعلمين، وزيادة المخصصات المالية لإدارة المدرسة لمواكبة التطورات السريعة في مجال التقتية، ووضع خطط لتحقيق أهداف العملية التعليمية، وتفعيل نتائج البحوث والدراسات التربوية الخاصة بتطوير العملية التريوية. أظهرت النتائج عدم وجود فروق ذات دلالة إحصائية بين متوسطات استجابات أفراد عينة الاراسة لجميع محاور الدراسة تعزى للمؤهل، والوظيفة، وعدد سنوات الخبرة، وعدد الدورات التدريبية في مجال إدارة العملية التربوية، وتتفق هذه النتيجة مع دراسة (عيسى، • 1 • ام) التي أظهرث عدم وجود فروق ذات دلالة إحصائية بين درجة ممارسة معلمي الدراسات الاجتماعية ومعلماتها لاستراتيجيات التدريس تعزى لثتلاثة متغيرات مستقلة وهي النوع، والمؤهل العلمي، والخبرة التدريسية، وتختلف مع دراسة (العتيبي، V . . r م) التي

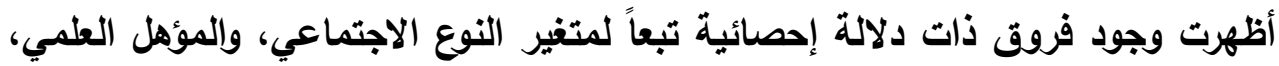

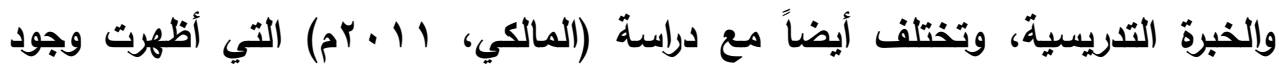
فروق ذات دلايّة إحصائية بين متوسطات استجابات أفراد عينة الدراسة حول درجة ممارسات القيادة الإبداعية في المدارس الحكومية المتوسطة بجدة من وجهة نظر مديريها ومعلميها وفقاً لمتغيرات المسمى الوظيفي، والمؤهل العلمي وعدد سنوات الخبرة. 


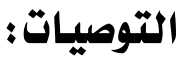

يمكن صياغة مجموعة من التوصيات الخاصة في إطار النتائج التي تم التوصل إليها وذنك فيما يلي :

توفير برامج تدريبية للقيادات المدرسية لتمكينها من أداعدورها حيال تحسين الأداء التدريسي للمعين وفق المعايير الوطنية للتبريس من واقع الوثائق الإستراتيجية لوزارة

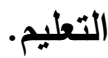
أهمية نشر ثقافة الجودة والمعايير في المجتمع المدرسي من قبل القيادات المدرسية،

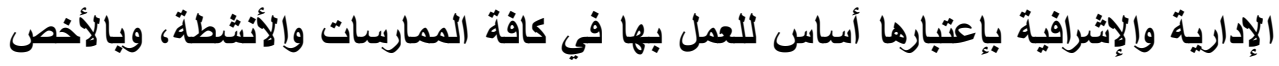

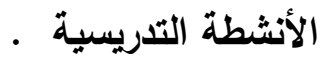

الريط بين المحاسبية التعليمية للمعلمين ويين تحقيق معايير جودة الأداء التدريسي في التخصات المختلفة ،وأن يراعي ذلك في التقارير السنوية التي تعدها الإدارة

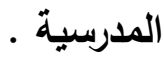
مشاركة المعلمين في عملية صياغة المعايير ومناقثة سبل تفعيلها في التخصصات والأنثطة الصفية واللاصفية تحت إثراف القيادات المدرسية والإشرافية . أن تسعى القيادات المدرسية لتوفير بيئة تعلم صحية تعين المطلمين على العمل

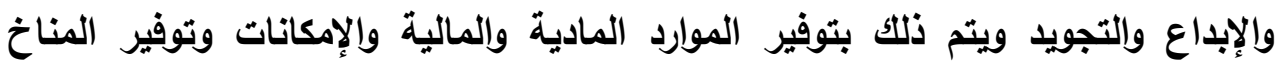
الديمقراطي والحرية الفكرية. 


\section{المراجع}

\section{أولاً : المراجع العربية}

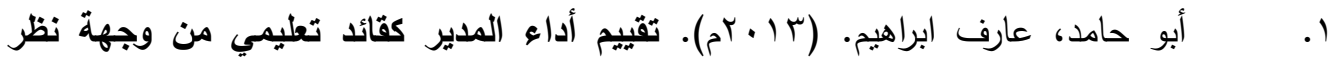
معلمي المدارس الأساسية في مدينة القدس. القدس: جامعة بيرزيت.

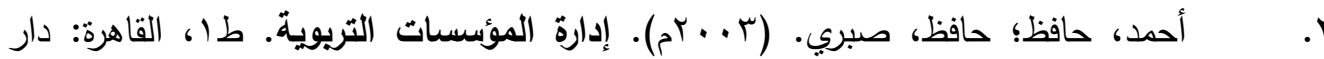
علاء للكثب r. أحمد، عدنان؛ الحفظي، يحيى. (v . . rم). إدارة الجودة الشاملة وتطبيقاتها في التعليم والإدارة المدرسية. أبها: مطابع آل ده.

ع. آل سحران، عبداله بن محمد بن عبداله. (V . . rم). العملية الإشرافية في إدارات التربية والتعليم ومراكز الإثراف التريوي في ضوء مبادئ الجودة الشاملة. رسالة ماجستير غير منشورة. كلية التربية، جامعة أم القرى. مكة المكرمة. جاد، إيناس. (ץ . . ץ). تقويم معلم الرياضيات لأدائه التدريسي بالمرحلة الإعدادية. رسالة ماجستير غير منشورة، كلية التربية، جامعة المنصورة، المنصورة، مصر .

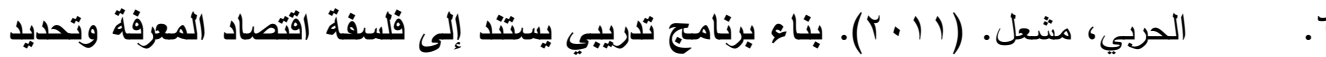
فاعليته في تطوير مهارات التدريس والاتجاهات المهنية لاى معلمي التعليم الصناعي. أطروحة دكتوراه غير منشورة، كلية الدراسات التربوية، جامعة عمان العربية، عمان، الأردن.

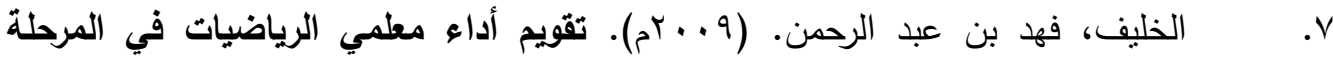
المتوسطة بمحافظة الرس في ضوء مهارات التدريس الحديثة، رسالة ماجستير غير منشورة، الرياض، جامعة الإمام محمد بن سعود الإسلامية.

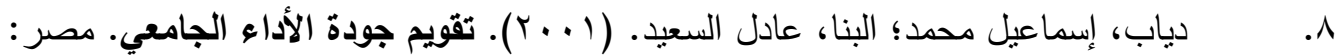
المكتبة المصرية.

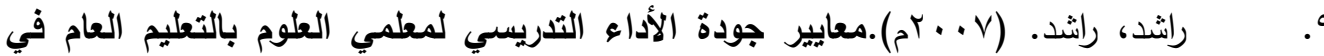
ضوء أبعاد التعليم. المؤتمر العلمي التاسع عشر "تطوير مناهج التعليم في ضوء معايير الجودة"

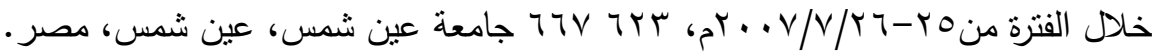




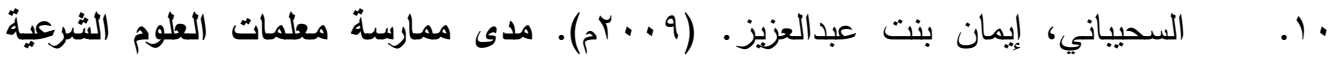
بالمرحلة المتوسطة لمهارات التفكير الإبداعي في أدائهن التدريسي. رسالة ماجستير غير منشورة. الرياض، جامعة الإمام محمد بن سعود الإسلامية.

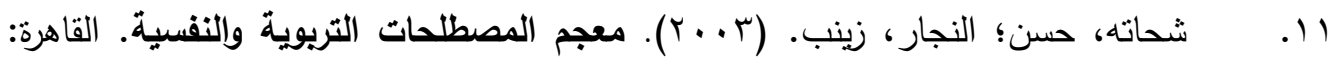

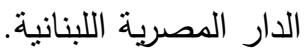

rا. شقير، علاء توفيق رشيد. (11 • rم). درجة ممارسة مديري المدارس ومديراتها للقيادة

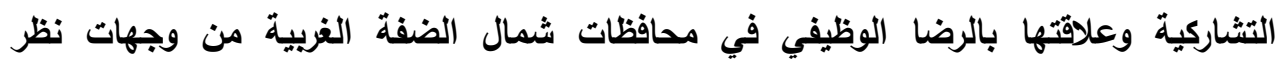
المعلمين والمعلمات فيها. رسالة ماجستير غير منشورة. غزة، الجامعة الإسلامية.

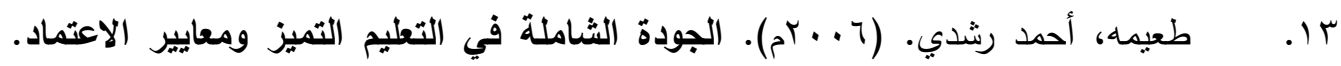
القاهرة: دار المسيرة للنشر والتوزيع.

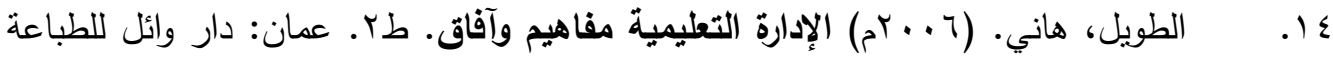
والنشر.

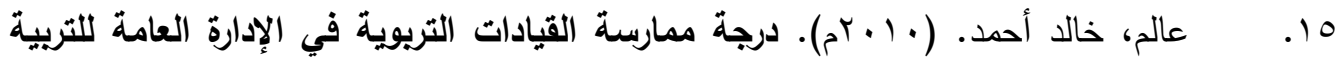
والتعليم للبنين بالعاصمة المقدة لعملية اتخاذ القرار. رسالة ماجستير غير منشورة. مكة

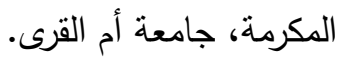

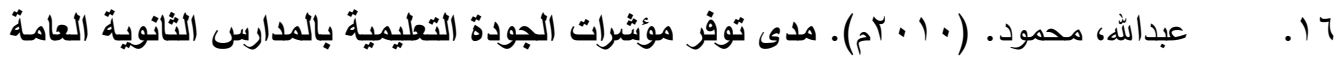
في مصر في ضوء المعايير القومية للتعليم. رسالة ماجستير غير منشورة. قسم أصول التربية،

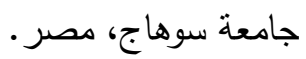

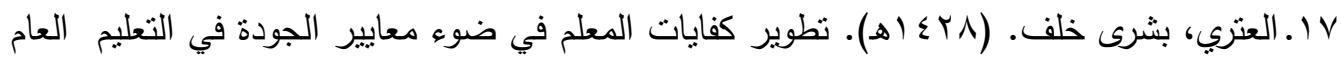

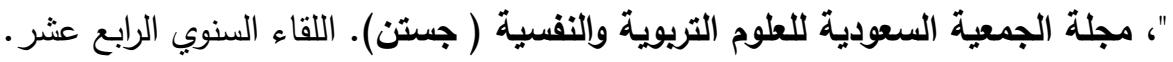

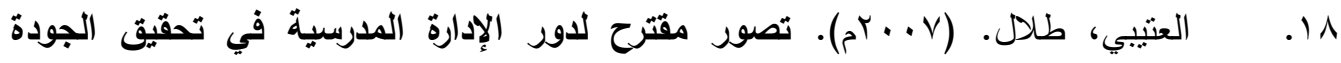
التعليمية بمدارس الثانوية العامة للبنين بمكة المكرمة. رسالة ماجستير غير منشورة. قسم الإدارة التربوية والتخطيط، كلية التربية، جامعة أم القرى، مكة المكرمة.

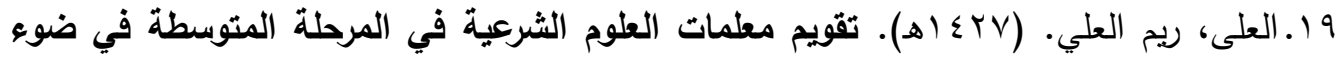
المعايير المقترحة لجودة الاداء التدريسي. رسالة ماجستير غير منشورة. كلية التربية، جامعة

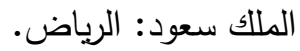

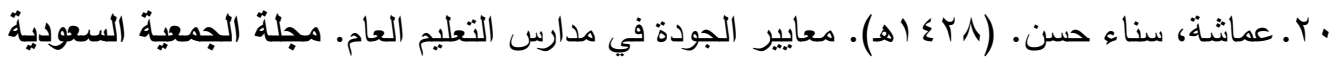

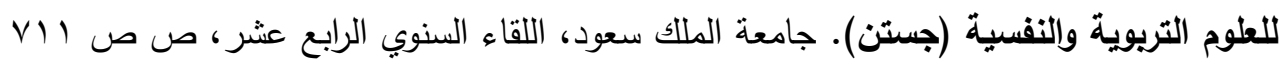


اY. . العمايرة، محمد حسن. (T . . (Y). تقدير أعضاء هيئة التدريس بجامعة الإسراء الخاصة بالأردن للمهام التعليمية المناطة بهم من وجهة نظر طلبتهم. مجلة العلوم التريوية. البحرين، كلية التربية، المجلد V، العدد r.

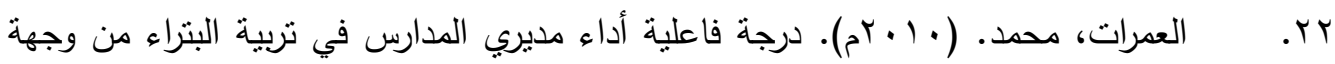

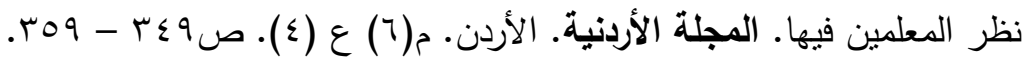

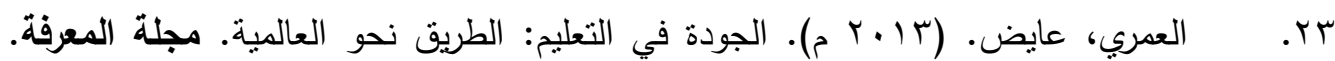
الرياض.

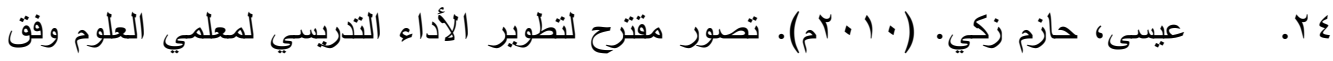
معايير الجودة في المرحلة الأساسية بمحافظات غزة. مجلة الجامعة الإسلامية. المجلد (1 ا) العدد

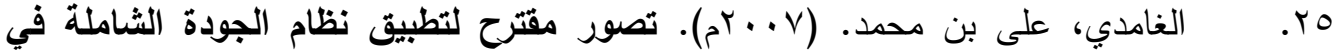
المؤسسات التريوية والتعليمية السعودية في ضوء المواصفة الدولية للجودة. القصيم، الجمعية السعودية للعلوم التربوية والنفسية (جستن).

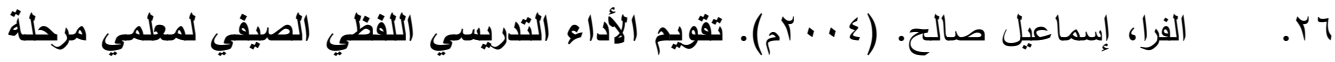
التعليم الأساسي، وثيقة عمل مقدمة لمؤتمر النوعية في التعليم الجامعي جامعة القدس.

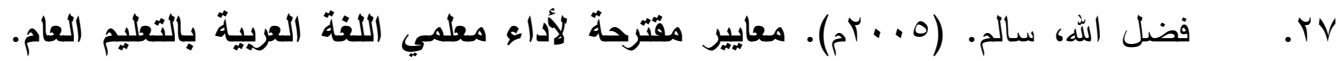
رسالة ماجستير غير منشورة، الرياض، جامعة الملك سعود.

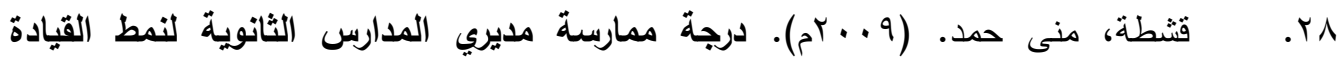
التريوية في ضوء المعاييز الإسلامية من وجهة نظر المعلمين وسبل تفعيلها. رسالة ماجستير غير منشورة. غزة، الجامعة الاسلامية.

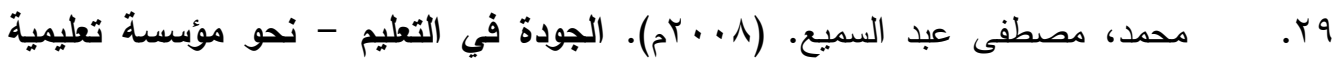
فاعلة في عالم متغير. المركز القومي للبحوث التربوية والتتمية بالتعاون مع مكتب اليونسكو الإقليمي.

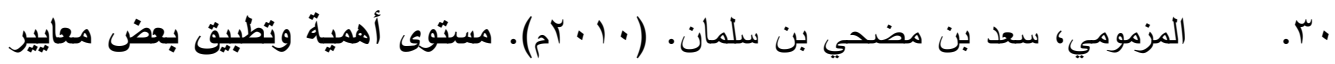
الجودة الشاملة في برامج تدريب المشرفين التربويين بمراكز التدريب التربوي بمدينة مكة المكرمة. رسالة ماجستير غير منشورة. مكة المكرمة، جامعة أم القرى. ا. مقابلة، محمد قاسم. (11 • (rم). التدريب التريوي والأساليب القيادية الحديثة وتطبيقاتها التريوية. طا ـ الرياض: دار الثروق للنشر والتوزبع. 


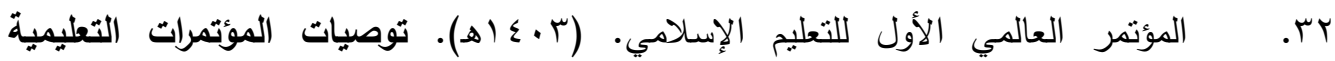

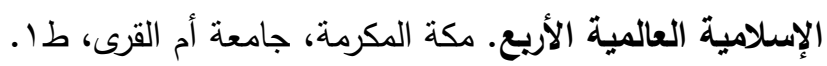

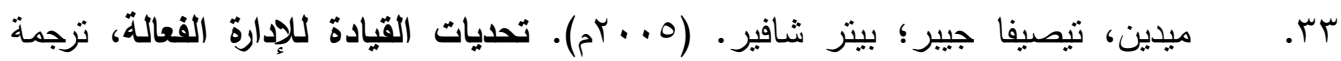

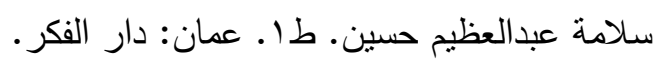

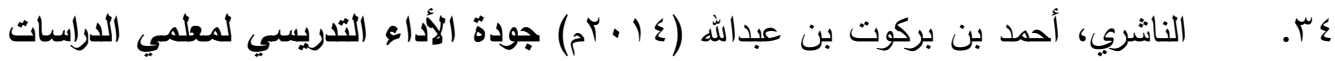
الاجتماعية والوطنية بالمرحلة المتوسطة في ضوء متطلبات اقتصاد المعرفة. رسالة ماجستير غير منشورة. مكة المكرمة، جامعة أم القرى.

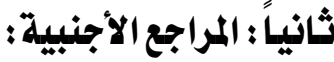

1. Borko، H.، et. Al.، Borko، h.، et al.‘(2006). Teachers Developing Ideas and Practices about Mathematics Performance assessment: Success stumbling Blocks، and Implications for Processional Development، University of Colorado، Boulder USA، Science Direct.

2. Detret، J. \& Others (2001). Quality Management In USA High School Evidence From The Field، School Leadership،12، (10)، 158- 178.

3.

eib, S. (2012).Education Professional Standards Board, "EPSB", New Teacher Standards for Preparation and Certification". Kentucky Performance Standards, July.

4. Marlette، Stephen George (2004). Characteristics of Superintendents Who are Effective Instructional Leaders. PHD Dissertation University of South California. U.S.A. 